NBER WORKING PAPER SERIES

\title{
THE ORGANIZATION OF R\&D IN AMERICAN CORPORATIONS: THE DETERMINANTS AND CONSEQUENCES OF DECENTRALIZATION
}

\author{
Ashish Arora \\ Sharon Belenzon \\ Luis A. Rios \\ Working Paper 17013 \\ http://www.nber.org/papers/w17013
}
NATIONAL BUREAU OF ECONOMIC RESEARCH
1050 Massachusetts Avenue
Cambridge, MA 02138

May 2011

We thank seminar participants at the 2010 NBER Summer institute, IFN Stockholm Conference, HBS TOM Seminar, Technion Israel Strategy Conference, as well as Nick Bloom, Tom Hubbard, Will Mitchell, Raffaella Sadun, Mark Schankerman, John Van Reenen, Nathan Letts and Ray Gilmartin for helpful comments. We thank Hadar Gafni for excellent research assistance. All remaining errors are our own. The views expressed herein are those of the authors and do not necessarily reflect the views of the National Bureau of Economic Research.

NBER working papers are circulated for discussion and comment purposes. They have not been peerreviewed or been subject to the review by the NBER Board of Directors that accompanies official NBER publications.

(C) 2011 by Ashish Arora, Sharon Belenzon, and Luis A. Rios. All rights reserved. Short sections of text, not to exceed two paragraphs, may be quoted without explicit permission provided that full credit, including $(\odot$ notice, is given to the source. 
The Organization of R\&D in American Corporations: The Determinants and Consequences of Decentralization

Ashish Arora, Sharon Belenzon, and Luis A. Rios

NBER Working Paper No. 17013

May 2011

JEL No. D23,D83,L22,O32

\begin{abstract}
We study the relationship between decentralization of $R \& D$, innovation and firm performance using a novel dataset on the organizational structure of 1,290 American publicly-listed corporations, 2,615 of their affiliate firms, as well as characteristics of 594,903 patents that they hold. We explore the tension between centralization and decentralization of $\mathrm{R} \& \mathrm{D}$, which trades off between responsiveness to immediate and local business needs and the type of research that can benefit the firm as a whole. To do this, we develop two novel measures of decentralization. First, using intra-firm patent assignments, we distinguish between patents that are assigned to the inventing unit rather than to corporate headquarters. Second, we exploit the variation between firms which posses a central corporate R\&D labs and those that do not. We find that centralized R\&D tends be more scientific, broader in scope, and have more technical impact, while being more likely in firms that operate within a narrower range of businesses, in complex technologies, or that are less reliant upon acquisitions. Additionally, we find that firms with a more decentralized structure, on average, invest less in $R \& D$, generate fewer patents per R\&D, and exhibit greater sales growth and higher market value. We discuss several theories that can explain these relationships, as well as potential avenues for future research.
\end{abstract}

Ashish Arora

Fuqua School of Business

Duke University

Box 90120

Durham, NC 27708-0120

and NBER

ashish.arora@duke.edu

Sharon Belenzon

Duke University

Fuqua School of Business

1 Towerview Drive, Durham, NC

United States

sharon.belenzon@duke.edu
Luis A. Rios

Duke University

luis.rios@duke.edu 


\section{Introduction}

Why do otherwise similar firms exhibit markedly different organizational structures? Though central to much theorizing in economics, strategic management, and organization studies, the internal organization of firms has received very little large-scale empirical analysis. In this paper we advance this exploration by analyzing new data that identifies whether an invention originates from a firm's corporate lab, in conjunction with data on the assignment of patent rights within large American firms, to measure decentralization of $\mathrm{R} \& \mathrm{D}$ in a firm. The main contribution of this paper is to document characteristics of research under different organization forms in large American corporations. We show that large American firms vary substantially in terms of their internal structure, and show that this structure has strong implications for innovation, such as R\&D investment and patenting intensity, and for overall firm performance, such as growth and market value.

R\&D is an important function, and there has been considerable empirical and theoretical work on the relationship between performance and R\&D investment (Henderson \& Cockburn, Penner-Hahn \& Shaver, 2005), and how firms link through R\&D alliances (Arora, Fosfuri, \& Gambardella, 2001; Mowery, Oxley, \& Silverman, 1996; Rosenkopf \& Almeida, 2003). However, possibly due to the difficulty of looking inside the black box of the firm, little empirical work has been devoted to exploring how firms organize R\&D internally, for example by centralizing or decentralizing this function. ${ }^{1}$ Though there is a growing literature on the geographical location and management of R\&D activities (e.g., Leiponen \& Helfat, 2010; Singh, 2008; Lahiri, 2010) especially across national boundaries (e.g. Audretsch and Feldman, 1996; Kuemmerle, 1999, Penner-Hahn and Shaver, 2006), the question of geography is logically distinct from the question of internal organization. ${ }^{2}$ For although the location of activities obviously has implications for how they should be managed, other considerations such as access to users, talented researchers, or knowledge spillovers are arguably more important considerations (Kogut, 1991; Alcácer, 2006; Jaffe, Trajtenberg, \& Henderson, 1993). By contrast, the salient trade-off in the internal organization of R\&D involves the allocation of decision making within the organization about

\footnotetext{
${ }^{1}$ Notable exceptions include DeSanctis, Glass \& Ensing, (2002), Birkinshaw, Nobel and Ridderstale (2002), Argyres and Silverman, Kastl et al., Kay, which are discussed in greater detail below.

${ }^{2}$ For example, as Singh puts it, a firm could have a decentralized formal organization even with relatively small number of $\mathrm{R} \& \mathrm{D}$ locations, while another firm might have a much more centralized organization despite having a much greater number of $\mathrm{R} \& \mathrm{D}$ locations.
} 
which R\&D projects to fund and how to manage them. This in turn focuses attention on differences in information and incentives within firms.

Our analysis is motivated by a trade-off between local information and the internal capture of spillovers. Though units may have superior local information, such as about the needs of their customers (Furman, 2003; Jensen \& Meckling, 1992; Von Hippel, 1998), unit managers may also be more likely to ignore the potential spillovers from their research for other parts of the firm (Nobel \& Birkinshaw, 1998), due to a lack of knowledge (Hitt \& Hoskisson, 1990), or because unit managers tend be rewarded principally for the performance of their own units, not that of the firm as a whole. The flipside of the this trade-off is that centralized R\&D, by being able to invest in longer term and riskier projects, can incorporate potential spillovers better, but may risk losing information on what customers need. Also, though corporate R\&D labs' resources may attract more talented researchers and thus increase productivity, these researchers may choose projects for their scientific interest rather than their economic potential alone. Put differently, in some instances, central R\&D labs may be subject to "capture" by the researchers employed there.

This basic trade-off has several implications for the conditions under which we should expect to observe decentralization and for the consequences of decentralization. In this study, we develop a novel dataset that details the organization of patent origination and patent assignment in a significant subset of American firms. We complement this with patent-level data on whether inventors were located in corporate R\&D labs or elsewhere in the organization (we discuss the strengths and weaknesses of our measures in section 3). It is plausible that decentralization of $R \& D$ is also associated with delegation of other types of authority for managing innovation, such as managing IP and licensing. However, for sharpness in exposition we speak of "R\&D decentralization" when the managers of divisions, business units or wholly owned subsidiaries (hereafter collectively referred to as "units") make the key decisions such as which types of R\&D projects should be funded, how the projects and the resulting IP should be managed. By contrast, "centralized" $\mathrm{R} \& \mathrm{D}$ is associated with a central $\mathrm{R} \& \mathrm{D}$ organization, managed by executives reporting to headquarters (rather than a unit), and typically conducted in a corporate R\&D lab.

Our paper combines data from several sources: (i) patent level information from the United States Patent and Trademark Office (USPTO), (ii) ownership structure data from Icarus and Amadeus by Bureau Van Dyke (BVD), (iii) data on location of corporate 
R\&D labs in the United States from the Directory of American Research and Technology, the US Office of Management and Budget's Core-Based Statistical Areas (CBSA areas) database, and a commercial zip-code matching database (iv) Merger and acquisition data from Thomson Reuters SDC Platinum and Zephyr by Bureau Van Dyke, (v) accounting information from U.S. Compustat. Our sample includes 595,396 patents that are matched to 1,491 American publicly-listed corporations, a total of 30,834 of their private and public units, of which 2,615 was assigned at least one patent.

We matched a total of 595,396 patents to our firm sample, where 112,428 of these patents $(18.9 \%)$ are assigned to units. To anticipate our results, we find that decentralization of $R \& D$ is more extensive for firms that operate in discrete technology industries, rely more heavily on acquisitions, and that manage a diverse range of technologies. Consistent with prior findings (Argyres \& Silverman, 2004), decentralized research is more incremental in nature, narrow in scope, and less likely to draw upon scientific research. In addition, we find that decentralized firms tend to invest less in $R \& D$ and generate fewer patents from their R\&D, but also grow faster. Intriguingly, we also find that whereas the existence of corporate labs is associated with higher market value, the extent of decentralization is positively associated with the market value of the firms. These findings underline the importance of $\mathrm{R} \& \mathrm{D}$ projects that focus on what customers want, while also pointing to the value that centralized $R \& D$ can create through greater efficiency and by coordinating projects to capture $R \& D$ spillovers. They suggest that firms may create more value from $R \& D$ by creatively linking central $R \& D$ to the needs of the downstream businesses.

Though we build upon a number of studies of the organization of $R \& D$ in large firms, our paper is novel in two important respects: Instead of survey-based measures or case studies used in the earlier studies, we develop a new measure based on patent assignments and supplemented by a direct measure of whether patents originate within a corporate R\&D lab, as opposed to originating in other parts of the firm. This enables us to use a much larger sample and allows for a systematic, large scale, empirical examination of the determinants of the organization of $\mathrm{R} \& \mathrm{D}$. Second, unlike the vast bulk of the previous literature, we also link $\mathrm{R} \& \mathrm{D}$ organization to measurable outcomes: sales growth and market value. Although we do not claim to establish causal relationships, we are able to provide a sounder empirical basis for various theoretical perspectives on organizational structure and the implications for firm performance. 
The rest of the paper is organized as follows. Section 2 places our paper in the literature. Section 3 develops our hypotheses on the contrasting implications of centralizing versus decentralized R\&D in multi-unit firms. In Section 4 we discuss the limitations of using patent assignments to measure the decentralization of $R \& D$, and how we mitigate some of the problems by using data on inventor location within the organization. Section 4 describes the data and our principal measures. Section 5 presents our empirical findings on how decentralization is related to the firm's environment, and the nature of its research. Section 6 explores the relationship between decentralization and outcomes. Section 7 concludes by summarizing our findings and discussing the implications for theory and practice as well as suggestions for future research.

\section{Decentralization of tasks and authority in organi- zations broadly defined}

\subsection{Organization of R\&D within multidivisional firms}

The tension between centralization and decentralization of R\&D in American corporations is well illustrated by Hounshell and Smith's (1988) classic study of R\&D at Du Pont, with its vivid description of the firm's oscillations between these forms. Du Pont's pre-WWI diversification efforts created a situation where centralized R\&D was deemed as insufficiently responsive to the needs of a diverse set of businesses which included explosives, celluloid plastics and films, lacquers, paints and varnishes, and dyestuffs. Consequently, individual business units were given authority in the 1920's over their R\&D activities, and each business created a separate research division. However, the various businesses were still connected by a common scientific base, as shown by the hugely successful nitrocellulose lacquer Duco, which was invented by the cellulose division instead of the paints and varnish division. Though Duco was a major success, it highlighted the problems with decentralized R\&D -these intra-firm spillovers required extensive coordination, which is better managed in a central R\&D organization. For instance, using Duco for furniture required additional technical advances in resins, which had to be carried out by Du Pont's central R\&D organization. Thus, under Charles Stine R\&D gradually swung back towards centralization which was again the dominant form by 1928. Centralization of R\&D was also motivated by growth opportunities. For instance, even as the rayon business matured, 
researchers in the rayon division were constrained to work only on cellulosic fibers (from which Rayon had come), and the general manager of the Rayon division was reluctant to authorize more broad ranging research in synthetic fibers. As one R\&D manager noted in 1933:

"In our some ten years rayon experience, we have in but two cases bent any part of our research program in a direction other than one relating directly to the most immediate manufacturing and selling problems ... Unless we conclude that there will be no radical departures in the synthetic fiber (or film) industry in the next ten years, then it must be concluded that our technical program falls short in its more radical and forward looking aspects" (Hounshell and Smith, 1988: 181-182).

The relevant point for our discussion, as Argyris and Silverman (2004) also stress, is that decentralized $R \& D$ tends to be product focused, whereas central R\&D groups are better able and better motivated to invest in more basic, non-specific R\&D. And sometimes this type of research yields huge payoffs, such as Nylon. A lesser known impact of this miracle fiber was the effect it had on the organization of R\&D at Du Pont, by providing the justification for a major investment in basic research and a focus on science. Indeed, the new laboratory for fundamental research was dubbed "Purity Hall" by Du Pont chemists, signifying its distance from the grubbier concerns of the businesses. This is another feature of centralized research: Along with a focus on non-specific research, centralized R\&D also tends to be more scientific in its orientation.

The strengths and weaknesses of centralized research are evident in other contexts as well. For example, IBM's scientists laid the foundations for relational databases, but IBM's database division (which rightfully should have commercialized it) was seemingly unaware of it until Larry Ellison's startup SDL (the precursor to Oracle) appropriated the technology from readily available IBM scientific publications (Bhaskarabhatla, 2010). It is unlikely that it would have been developed in a more product oriented divisional R\&D lab. Yet, as the example also shows, the origins in central R\&D also hindered its exploitation by the business unit. 


\section{$2.2 \quad$ The Trade-off}

These examples show both the power of centralization and the potential drawbacks which may encourage decentralization. Scholars have emphasized many channels through which decentralization in general may affect behavior, such as decentralization being associated with higher flexibility (Child, 1984; Mintzberg, 1979), independence (Kanter, 1985), initiative (Chandler, 1977), or merely through the motivation arising from the perception of freedom (Gupta and Govindarajan, 2000) or pride of ownership (Estrin et al. 1987). Our paper, however, is specifically focused on the inherent trade-offs between centralization and decentralization of $\mathrm{R} \& \mathrm{D}$, and contributes to the literature broadly motivated by similar questions. Nobel and Birkinshaw's (1987) studied the organization of R\&D in a sample of $115 \mathrm{MNCs}$, relating the type of R\&D unit to how it is managed. Subsequent work such as Birkinshaw et al., (2002) explored a related aspect of R\&D organization, namely whether R\&D units have autonomy and whether they are integrated with other units. Using a combination of case studies and surveys they found that $R \& D$ that adapts technology to the needs of local units is decentralized, whereas R\&D for creating new knowledge is more centralized.

However, our study differs from these in three important ways. First, by concentrating in US-based firms we strip away the international component (and its various countylevel confounding factors (Kogut, 1991)). Second, we rely upon observable patent-based measures instead of the survey measures that often underpin intra-organizational study (e.g. Cohen \& Levinthal, 1990 ), and as a result, have much larger sample sizes. Third, and most importantly, our study also links outcomes to decentralization instead of simply exploring how R\&D decentralization is related to the nature of $R \& D$.

Kay (1988) discusses characteristics of R\&D projects that increase the tendency towards increased centralization. First, since a project may feed into several downstream products, R\&D has potential economies of scope. However, individual business units would be less likely to invest in R\&D projects that provide benefits to other units in the firm (Hitt \& Hoskisson, 1990; Saxenian, 1994; Feinberg \& Gupta, 2004; Gupta \& Govindarajan, 2000; Nobel \& Birkinshaw, 1998; Hitt \& Hoskisson, 1990; Saxenian, 1994)). Second, R\&D has uncertain returns, which combined with the fact that business unit managers are mobile (Podolny \& Baron, 1997), will disfavor projects where the payoff 
may come after a manager has moved on to other firm or unit. Mobile managers will also disfavor investment R\&D projects with long lags and lumpy investments (Argyres \& Silverman, 2004; Cockburn, Henderson, \& Stern, 1999; Ghemawat, 1987; Leiponen \& Helfat, 2010; Roberts \& McEvily, 2004). Consistent with this, Galunic and Eisenhardt (2001) find that corporate managers are more likely to pursue opportunities in new markets than are unit managers. Henderson and Clark (1990) conclude that central R\&D labs are less reliant on local information channels and more likely to explore broader architectural innovations. Lerner and Wulff (2007) find that in firms with centralized R\&D, long-term incentives for managers go together with more heavily cited and original patents, but that this effect does not exist in firm with decentralized R\&D structures, suggesting that centralized $\mathrm{R} \& \mathrm{D}$ is more conducive to encouraging more original research.

On the other hand, there are counteracting influences for some R\&D to be conducted and managed by the individual business units (and increase the tendency toward decreased centralization). Individual units may have superior access to local knowledge, such as information about customer needs, and therefore better evaluate what sorts of projects will have a higher payoff. Also, central R\&D is effectively financed by a tax on individual business units, which potentially distorts incentives inside firms (Kay, 1988). More importantly perhaps, as the R\&D management literature has repeatedly found (Hill, Martin, \& Harris, 2000; Kline \& Rosenberg, 1986; Reger, 1999) a close interaction between R\&D and functions such as marketing and manufacturing is often the difference between success and failure.

Our work is also related to a large economics literature on decentralization of tasks and authority in organizations. This work tents to be theoretical (see Mookherjee 2004 for a review of the economics literature), and empirical studies remain scarce. Most of the empirical studies focus on the impact of changes in communication costs or the adoption of information technology. For example, using US data, Rajan and Wulf (2005) provide empirical evidence that firms tend to select flatter organizational structures in more recent years relative to the past. Bresnahan, Brynjolfsson and Hitt (2002) and Caroli and Van Reenen (2001) find that with greater investment in information technology, firms tend to adopt more decentralized organizational structures. Acemoglu et al. (2007) find that British and French manufacturing firms in the 1990s closer to the technological frontier, operating in more heterogeneous environments, or younger, are more likely to decentralize. 
Colombo and Delmastro (2004) find that local information increases decentralization to plant managers in Italian firms, as does superior communication technology, but centralization increases with the need for coordination. Bloom, Sadun, and Van Reenen (2008) find that trust and social norms increase decentralization as does product market competition (interpreted as a proxy for importance of local information). These empirical exercises generally frame the issue in terms of differences in information (e.g., Radner and Jacob Marschak 1972) and differences in incentives within firms.

In our context, a unit may have more information than headquarters about which research projects are worth pursuing, which inventions are worth patenting, which patents are worth maintaining and enforcing, and which licensing deals are worthwhile. Superior information implies that the unit can make better decisions. For instance, Bradley, et. al. (2010) conclude that greater decentralization enables unit mangers to exercise greater discretion in dealing with the demands of the unit's environment. However, though better informed about its own needs, the unit may be ill-informed about those other parts of the firm. Thus, leaving the unit with the authority over these decisions has to be balanced against other considerations. One is the cost and time involved in communicating the relevant information up the hierarchy, needed to coordinate the actions of the various units. The cost of information transfer need not only be physical costs and delay. The unit, though having superior information, may hide it or shade it because its interests are not fully aligned with those of the firm as a whole. This consideration animate both the theory of transaction costs (e.g., Williamson, 1975) and the principal-agent theory (Jensen and Meckling, 1992). The property rights view provides a complementary perspective. Managers in the unit may fear being "held-up" by top management, and thus underinvest. Decentralization is a means of credibly assuring them against such expropriation. For instance, Riordan (1990) provides a model in which a principal delegates authority to provide incentives for cost reduction. Aghion and Tirole (1997) provide a model in which a principal delegates authority as a credible way of leaving information rents with the agent, so as to provide incentives for suitable choice of projects. Similarly, Belenzon, Berkovitz and Bolton (2009) argue that units in business groups have superior incentives to invest in more basic innovation because they enjoy greater legal protection against the "parent" firm expropriating their rents from innovation.

Two recent studies address the trade-off we are concerned with more directly, and pro- 
vide useful touch points for our paper. Kastl et al. (2009) frame their study of mostly small Italian manufacturing firms in terms of whether decentralization - delegation of authority regarding $\mathrm{R} \& \mathrm{D}$ as well as financial, administrative and business decisions to divisions and units - provides superior incentives for investment in R\&D. They find that decentralization is associated with greater investments in $R \& D$ in Italian manufacturing firms. They also explore the determinants of decentralization and find, contrary to Acemoglu et al. (2007), that age, distance to the technology frontier, and heterogeneity of the environment are not associated with decentralization. Argyres \& Silverman (2004) study the organization of R\&D in a sample of 71 large US corporations, focusing specifically on the organization of $\mathrm{R} \& \mathrm{D}$, rather than the organization of the firm more broadly (in contrast to Kastl, et.al.). They hypothesize and find that decentralized R\&D results in lower impact research outcomes, and with research that is narrower in technical and organizational scope. Once again, our study is distinctive in a number of respects. As discussed above, we do not use survey based measures of decentralization. Instead, we use observed behavior (i.e., whether patents are assigned to the parent entity or decentralized to divisions) as a measure of the extent of decentralization, complemented by whether the patent was produced by a corporate R\&D lab. Patent data are widely available and our study opens the possibility for further research using patent assignments in this manner. Our sample also differs significantly, as it consists of nearly 1,300 large, publicly traded, US firms, allowing us to explore both the determinants and consequences of decentralization. Thus, we study not only the nature of R\&D (Argyres \& Silverman, 2004) and the amount of R\&D (Kastl, Martimort, \& Piccolo, 2009), we also study how decentralization is related to patenting behavior itself (i.e., we estimate a patent production function). Moreover, we also study how the extent of decentralization is related to sales growth and the market value of the firm.

\section{Hypotheses}

We have three main sets of hypotheses. The first concerns the nature of decentralized research activities as compared to centralized activities. The second concerns the implications of decentralization for extent of investment in R\&D and patenting, and third concerns the consequences for growth and market value. 


\subsection{The nature of decentralized research:}

Since unit managers are rewarded primarily for the short-term performance of their own unit, they will tend to favor research projects with short term goals, and disfavor pioneering projects. Consequently, units will have limited incentives to invest in research that could spill over to other parts of the firm. Indeed, competition for resources inside the firm may create incentives against such research, lest it allow other divisions to use the fruits of the research and claim additional resources, as was the case with Duco and the Cellulose Division in Du Pont. Siggelkow and Rivkin (2006) argue that delegation will enable low-level managers to screen out alternatives that do not serve their parochial interests. By contrast, centralized $R \& D$ is conducive to more pioneering research, research that explores new markets, and more fundamental advances (Galunic and Eisenhardt 2001; Henderson and Clark, 1990; Lerner and Wulff, 2007). Furthermore, centralization of R\&D also facilitates greater coordination across the various units. This coordination is more valuable when the units share common technologies (i.e., are more closely related) or if the products (of the various units) themselves must be mutually compatible or have other forms of inter-dependencies. Thus, centralization of R\&D is more likely to be observed when the firm operates a narrow range of businesses, or if the underlying technology is "complex", with marketable products being composed of many different parts, produced by distinct businesses (Brusoni, Prencipe, \& Pavitt, 2001; Cohen, Nelson and Walsh, 2000). Firms also differ both in the extent to which they acquire other businesses, and how they deal with such acquisitions. Centralization is obviously easier to manage if acquisitions are relatively rare, because each acquisition would then require integration of new research teams and organizations (Casciaro \& Piskorski, 2005; Grossman \& Hart, 1986; Szulanski, 1996). Conversely, decentralized firms would naturally find it easier to deal with acquisitions.

Following conventional practice in the management and strategy literature, we restate the above as hypotheses. We couch our hypotheses as patterns of association we expect in the data, rather than as causal relationships. The causal relationships underlying these relationships are important. However, examining whether the expected patterns of association exist is a test, though not a conclusive one, of the predictions of the underlying theories. Moreover, establishing causality would require identifying exogenous sources in 
variation in how firms organize their $\mathrm{R} \& \mathrm{D}$, a topic we leave for future research. For clarity, we have compared two ideal types, centralization and decentralization. However, as Siggelkow and Levinthal (2003) argue, and as Du Pont's history shows, firms will often try to get the best of both worlds by developing hybrid structures. These structures can take two complementary forms. First, central R\&D labs can coexist with R\&D in units. Central labs take on more fundamental and longer range projects while units undertake more product -focused and short-term projects (consistent with the hypotheses developed below). Insofar as R\&D itself is subject to scale economies - small labs may not be viable or cost effective - firms may concentrate activities in central labs but force the labs to devote some fraction of their efforts on projects desired by units. In effect, the labs become a seller of $R \& D$ services to the units. Conceptually, this is a hybrid form of $R \& D$ organization, where decentralization of authority is not coterminous with decentralization of the location of the activity. Although we do not theorize about this hybrid form of organization, we explore this distinction in our empirical analysis.

Hypothesis 1: Centralized R\&D is more likely to be observed in firms where spillovers are greater: firms operating in a narrow range of businesses, in more closely related businesses, and in complex technologies. Centralized R\&D is less likely in firms that actively acquire external businesses.

Hypothesis 2: Centralized R\&D will be more scientific in orientation, broader in scope, and have more technical impact. Conversely, decentralized R\&D will be less scientific, narrower in scope, and incremental.

\subsection{Organization of $\mathrm{R} \& \mathrm{D}$ and investment}

Theoretical perspectives provide less pointed guidance on how the different organizational forms are associated with outcomes. For instance, the quantum of R\&D investment by a firm can have a complex relationship with how the firm organizes its $R \& D$, in part because firms facing richer opportunities for technical advancement are more likely to develop central R\&D labs to exploit those opportunities. Even holding opportunities and other factors constant, however, centralization will be associated with greater $R \& D$ investment. Intuitively, suppose that the firm decides on a cost of capital (a hurdle rate of return that projects must meet), and the units choose $R \& D$ projects that exceed the hurdle rate. One can imagine budgets of corporate $\mathrm{R} \& \mathrm{D}$ labs being decided in a similar 
fashion. If the hurdle rates for the two are the same, then units will invest less in R\&D than corporate labs, because units will ignore potential spillovers to other parts of the firm (perhaps because they are unaware of the spillovers). This is an instance of the more general result that activities with positive externalities will be underprovided by a decentralized system (such as a market). Central R\&D labs will take a broader view of the benefits flowing from their research, and thus are likely to undertake projects that would be rejected by a unit with more parochial interests (see H1). Furthermore, whereas R\&D in units are typically part of a profit center (with competing claims for the overall investments the unit makes), central labs are typically cost centers. The net result is that a greater decentralization of innovation activities in a firm should be associated with lower investment in R\&D.

The difference in the types of research projects undertaken, discussed in $\mathrm{H} 2$ also has implications for patent propensity. Insofar as decentralized R\&D projects are focused on improving existing products and processes, and less likely than central R\&D projects to pioneer new products and technologies, their results may be intrinsically less patentable. In some cases, units are more likely to forgo patents, because patents are sometimes options on the future. Unit managers may be less willing to invest in such long-term options, at least as compared with managers of central R\&D labs. Thus, decentralization should be associated with fewer patents per dollar of R\&D investment. Conversely, insofar as centralized R\&D projects are broader in scope and more scientific in orientation, the outcomes are more patentable as well. Further, central R\&D labs may have greater incentives to patent as a way of signaling their productivity and justifying their budgets. By contrast, R\&D in units is more likely to be measured by how it contributes to the performance of the unit, rather than solely by measures such as patenting and publication. Formally we have that:

Hypothesis 3: Greater centralization of $R \& D$ is associated with greater investments in $\mathrm{R} \& \mathrm{D}$, and with greater patenting propensity.

\subsection{Organization of R\&D and outcomes}

The organization of R\&D not only affects the type and number of R\&D projects that

are funded but also but also the effectiveness of the R\&D effort. On the face of it, the implications for performance are ambiguous. However, we can identify some more nuanced 
implications for sales and value creation.

Decentralized research should help the business unit grow by improving products and reducing costs. However, centralized research can help develop new markets. However, insofar as decentralization also brings greater control over IP management, it should also result in less licensing. This is because unit managers are typically rewarded for sales and profit growth, and so are more likely than central licensing units to eschew licensing opportunities which might strengthen competitors and hurt their own sales, even if the licensing revenues more than offset the implied profit loss at the corporate level (see Arora, Fosfuri and Roende, 2010 for a formal model). More generally, greater autonomy to units may result in "empire building" by unit managers, which would also manifest is higher sales growth.

Though perhaps associated with higher sales growth, decentralization of R\&D need not result in greater value creation. Indeed, neither theory nor historical experience suggest that either form of organization is overall superior to the other. The neglect of spillovers and the reluctance to invest in longer-term research will result in unrealized opportunities for value creation under decentralized research. Conversely, though centralization may capture spillovers more effectively and pioneer technologies for new markets, central R\&D labs are also less knowledgeable about and less responsive to the needs of existing customers. However, though neither form is more valuable on average, the value created by the marginal project under each form will systematically differ. As H3 posits, units will underinvest in R\&D, particularly that which has potential spillovers for the firm as a whole, so that the marginal R\&D project by units creates more value for the firm than its cost. There is no reason to believe that central labs underinvest. Moreover, since central labs are also prone to capture by researchers that value scientific curiosity, the marginal centralized R\&D project may even actually destroy value.

Since theory does not predict that either form of organization is superior to the other, the empirical implications are subtle. Firms will create central R\&D labs when rich opportunities for significant technical advance exist, as hypothesized in H1. It follows that a central lab may be associated with greater value because it signals richer technical opportunities. Further, the value of centralized research will be greater when spillovers are more probable. Put differently, centralized research is more valuable when the firm's businesses share a technical base, as is the case when the businesses are closely related. However, the 
marginal project of units will be more valuable than the marginal project in central R\&D labs. Collecting these implications together we have:

Hypothesis 4a: The value of centralized research is greater when $R \& D$ spillovers are more likely. The marginal value from decentralized research is greater than from centralized research.

Hypothesis 4b: The marginal value created from decentralized research is greater than from centralized research.

\section{Data and measures}

Our paper combines data from several sources: (i) patent level information from the United States Patent and Trademark Office (USPTO), (ii) ownership structure data from Icarus and Amadeus by Bureau Van Dyke (BVD), (iii) Merger and acquisition data from Thomson Reuters SDC Platinum and Zephyr by Bureau Van Dyke, and (iv) accounting information from U.S. Compustat. The Appendix details the procedures used to construct the various datasets that comprise our platform.

Patents. Patent data are from the USPTO for the period 1975-2007. We match all granted patents to our sample of publicly traded American firms and their American affiliates. The matching is based on comparing the assignee name and address as it appears on the patent document to the name and address of companies in Icarus and Zephyr. Thus we are able to distinguish between centrally assigned patents - patents that are directly assigned to the parent company, and decentralized patents - patents that are assigned to affiliates. We matched a total of 594,903 patents to our final sample of Compustat firms. 107,654 of these patents $(18.1 \%$ ) are assigned to affiliates (that is, separate legal entities that are different from the headquarters firm).

Patent quality. We measure patent quality using the number of forward citations the patent receives over its life-cycle. Our Basic characteristics variables include the number of citations the patent makes to non-patent (scientific) literature, generality and originality. ${ }^{3}$

\footnotetext{
${ }^{3}$ We follow the widely accepted methodology developed by Trajtenberg, Henderson and Jaffe (1997) and define patent generality as inversely proportional to the concentration of the citations it receives across technology areas. Patent $i$ 's generality, $G_{i}$, is computed as:
}

$$
G_{i}=1-\sum_{j}\left(\frac{C_{i j}}{C_{i}}\right)^{2}
$$


The number of citations the patent makes to scientific article is an indication of the extent the patent relies on scientific knowledge. Generality is measured as the breadth of the technology areas across which a patent's citations are dispersed, and Originality is the equivalent measure for the citations contained in the patent.

Parent firms and units. Ownership data consists of two parts: cross-sectional ownership information from Icarus and Amadeus for 2008, and M\&A data from SDC Platinum and Zephyr. The cross-sectional data informs us on existing active affiliates, and the M\&A data informs us on historical affiliates that may have dissolved or been fully integrated by the parent company, as well as those that have been kept independent. The appendix provides details on the ownership algorithm used for affiliates identification and classification.

We supplement and confirm our ownership data by manually collecting information on all affiliates from the U.S. Securities and Exchange Commission's EDGAR database , firms' annual reports, and from detailed on-line searches. We identify 'dormant' affiliates - wholly owned subsidiaries with no significant economic activity that are founded mostly for tax purposes, as well as affiliates that are established solely as holding vehicles for the purpose of IP management. ${ }^{4}$ Patents that are assigned to these affiliates are classified as being assigned to the parent company. This screening leaves us with a total of 30,834 affiliated firms. Of these, 2,615 firms are assigned at least one patent during our sample period, and thus are kept in the sample.

Where, $j$ denotes citing three-digit U.S. class (419 classes), $C_{i j}$ is the number of citations received by patent $i$ from patents in technology field $j$ and $C_{i}$ is the total number of citations received by patent $i$. Following Hall $(2002)$ we correct $G_{i}$ for the number of citations received, as $\widehat{G_{i}}=\left(\frac{C_{i}}{C_{i}-1}\right) G_{i}$. In addition to patent generality, we also include patent originality, which is the equivalent measure for the concentration across technology fields of the citations made by the patent.

${ }^{4}$ For each acquired firm we determine whether it remained operational post-acquisition in several steps. First, we check whether the firm appears in Amadeus or Icarus as a distinct company. Second, we manually check each company listed in the first step whether it continues to operate independently from the parent company. We check their corporate websites to confirm that their legal disclaimers and investor relations information references a parent company. Dissolved acquisitions are much more problematic. Because we match patents to firms based on the 2008 ownership structure, we lose historical acquisitions that were fully integrated in the parent company and ceased to exist as separate legal entities. Though we do capture post-acquisition patents as those are likely to be assigned to headquarters, we may nonetheless over measure decentralization (because all historical patents that we do not match are centralized). To mitigate this problem we performed an exhaustive manual search to identify a significant majority of these absorbed firms and match them to their patents. Appendix A.1.3 for a description of this process. 


\subsection{Measuring decentralization of R\&D: Patent assignments and patents from corporate $R \& D$ labs}

Assignment. We use the share of patents that are assigned to its wholly-owned American affiliates as our first measure of decentralization. This measure has the advantage of being based on observed behavior, useful for large samples, and because it is not based on ad hoc surveys, deployable in other settings. Still, its use as a measure of decentralization of $\mathrm{R} \& \mathrm{D}$ raises several issues.

It is possible that a non-incorporated business or division inside a firm have de facto authority over its R\&D and innovation, but, because it is not a distinct legal entity, not have patents assigned to it. In other words, assignment of patents to affiliates may be a sufficient, but not necessary condition for decentralization of R\&D. Even so, our interviews with R\&D and IP managers suggest that the very fact that a unit is a distinct entity, rather than merely a division of the parent, suggests that the unit enjoys some autonomy The assignment of patents is a signal, that the unit enjoys a significant measure of autonomy. For example, Genentech, though wholly-owned by Hoffman La Roche, directly contracts on licensing the patents in its charge to outside firms. Assignment may also reinforce the identification and long-term ties between a manager and the patents she manages, so that opportunistic behavior becomes costly in terms of reputation (Gibbons, et al., 1999; Alonso and Matoushek, 2007). ${ }^{5}$

Mergers and acquisitions are an important source of variation in our data because decentralized firms acquire other firms and the patents that come along with them. We include in decentralization all patents of the affiliate on the grounds that the acquirer could have chosen to reassign those patents to the parent company post acquisition. Indeed, companies that are centralized will reassign patents from the affiliate to the parent. Companies which choose not to reassign such acquired patents also tend to assign patents to the affiliate after acquisition. ${ }^{6}$ Our results remain unchanged if we use only patents

\footnotetext{
${ }^{5}$ A different interpretation, which also supports the delegation of authority interpretation, is that units which may be potentially divested in the future are also likely to be assigned the patents they generate. For instance, one of the managers we interviewed pointed to the difficulties Motorola faced when divesting its semiconductors manufacturing business (now called Freescale Semiconductors), in sorting out which Motorola patents were going to be assigned to the divested business.

${ }^{6}$ The share of reassigned patents is similar between M\&A and internal patents. For M\&A patents, $8 \%$ are reassigned (8,410 patents), where for internal patents, $7 \%$ are reassigned $(32,834$ patents). For M\&A-related reassignments, $23 \%$ are reassignments from affiliates to headquarters, where for internal
} 
produced post-acquisition. However, we acknowledge that our assignment measure may capture not simply how R\&D is organized but also how IP management is organized.

A related issue is that patent assignments may reflect merely the authority to manage IP management rather than R\&D. Our interviews suggest otherwise: R\&D managers and IP managers we interviewed agreed that when patents are assigned to units from projects that the units managed (and paid for out of their R\&D budgets).

Patent assignments are sometimes driven by income tax strategies. Indeed, within our sample, some firms were found to assign all patents to wholly owned subsidiaries located in states with favorable tax conditions, such as lack of tax on royalty incomes. To mitigate this, we conservatively classify all such assignments as if the patents were assigned to the parent firm, even if they were assigned to an affiliate in the favorable state. Patent assignment may also be driven by a desire to have patents assigned in the name of the relevant business to make it easier to assert patents, obtain injunctions, and receive adequate damages. However, they could just as well be assigned to the parent for reputational reasons (Agarwal, Ganco, \& Ziedonis, 2009). Thus, patent assignments likely measure decentralization of R\&D with error. Although this is not classical measurement error, it is likely that the estimated coefficients suffer from attenuation bias. Another potential concern, which is less salient in our context, is that it is logically possible that a unit may receive patent assignments without enjoying the hypothesized autonomy. To better understand the importantce of this conceren we conducted several interviews with IP managers, attorneys, and high level executive at firms across industries within our sample. All of these discussion reinforced the interpretation that unit-assignment is strongly associated with effective delegation of authority in the R\&D process. In fact, not one person interviewed found this association surprising.

Corporate RED labs. We supplement the assignment measure with a different measure of the R\&D structure. Using information on corporate R\&D labs, we match whether the inventors are located close to the corporate labs. One limitation faced by many studies that utilize location as a measure concerns the multiple towns and cities that are often within the same metropolitan region. Thus, relying solely on Zip code or city name, one would miss that Boston and Cambridge facilities may in fact be within the same R\&D complex. This is even more problematic when we match to inventors, since inventors' patents, about $91 \%$ of reassignments are from headquarters to affiliates. 
addresses are more prone to variation within the area around an R\&D lab (as they live in suburbs, etc.). To counter this, we match our data to two different databases, one which converts city names to Zip codes, and one from the US Census Bureau which matches Zip Codes to the US Office of Management and Budget's Core-Based Statistical Areas (CBSA areas). We use the Directory of American Research and Technology, which lists such facilities for all publicly traded companies in America. This gives us the city and zip code information for each firm's R\&D lab. Similarly, we obtain inventor information for all patents from the USPTO database. Once we have identified the CBSA code for each inventor and each lab, we identify every patent in our sample where at least one inventor is located in the same CBSA as a lab (at the firm level). Our results are unchanged if we define patents generated by corporate $R \& D$ labs as those where every inventor is located in the same CBSA as a lab.

Patents generated by corporate R\&D labs should reflect the fruits of centralized research because corporate R\&D labs are typically part of a central R\&D organization, reporting into corporate headquarters through corporate $\mathrm{R} \& \mathrm{D}$ managers rather than to heads of divisions. By contrast, patents not generated from corporate R\&D labs should reflect the $R \& D$ activities taking place in units, especially in the $R \& D$, engineering and manufacturing functions in the units. Thus, the share of patents generated by corporate R\&D labs is another measure of the decentralization of R\&D. We find empirical support in our data for this assumption, as the vast majority of patents produced by corporate R\&D labs are indeed assigned to the parent firm.

As with assignments, using corporate labs to measure R\&D centralization could be misleading if the firm's central R\&D is not associated with a registered corporate lab. In particular, many firms do not have a registered corporate labs, pointing to the lumpy nature of such facilities. Moreover, the R\&D activities relevant to units may take place in corporate R\&D labs (or in collaboration with them). This makes sense because although the theoretical discussion has contrasted centralized and decentralized R\&D, many firms are likely to form hybrid arrangements in their search for the best of both systems (Siggelkow \& Rivkin, 2006). Indeed, a significant share of patents assigned to affiliates comes from corporate R\&D labs, perhaps reflecting a hybrid arrangement, where research is performed in a corporate lab but where the project is chosen, paid for, and perhaps even managed (through a matrix reporting arrangement) by the unit. Based on our in- 
terviews, we conclude that in such cases the resulting patents would generally be assigned to the relevant unit. In other words, these two empirical proxies - patents generated outside corporate labs and patent assignment to units measure related but different facets of $\mathrm{R} \& \mathrm{D}$ decentralization in an organization. In general, we find that the two measures provide qualitatively similar results, although there are differences in statistical and economic significance, which we discuss in section 5 .

Accounting and financial data. Accounting data are from U.S. Compustat. We match our firms using a string name process similar to the one we utilize to match patents to our ownership structure data. Please see Appendix A.2.2 for details on the algorithms. The book value of capital is the net stock of property, plant and equipment; Employment is the number of employees. $R \& D$ is used to create $R \& D$ capital stocks calculated using a perpetual inventory method with a $15 \%$ depreciation rate (Hall, Jaffe and Trajtenberg, 2005). So the R\&D stock, $G R D$, in year $t$ is $G R D_{t}=R_{t}+(1-\delta) G R D_{t-1}$ where $R_{t}$ is the R\&D expenditure in year $t$ and $\delta=0.15$. Patents stock, GPat , is calculated in an analogous way. Patents stock in year $t$ is SPat $_{t}=P_{t}+(1-\delta) G P a t_{t-1}$ where $P_{t}$ is the citations-weights flow of patents in year $t$. To control for patent quality we weight each patent by the ratio between the number of citations it receives and one plus the average number of citations received by all patents that were granted in the same year (one is added to both numerator and denominator to avoid zero weights). Firm value is the sum of the values of common stock, preferred stock and total debt net of current assets. The book value of capital includes net plant, property and equipment, inventories, investments in unconsolidated subsidiaries and intangibles other than R\&D. Tobin's Q (market value over capital) was winsorized by setting it to 0.1 for values below 0.1 and at 20 for values above 20 .

Table 1 provides summary statistics on our firm sample. Our sample's average firm is valued at $\$ 1.4$ billion, has $\$ 3.6$ billion in sales, $\$ 488$ million in R\&D stock, and holds a stock of 132 cites-weighted patents. The share of patents that are assigned to affiliates across firms is $36 \%$. Using the patent as the unit of analysis, $18.1 \%$ of patents are assigned to affiliates (as we shall see later, firms that patent a lot are less likely to assign patents to affiliates, which explains the difference between patent and firm-level assignment). The average patent receives 8.9 (or 11.3 when restricting the sample to patents that receive at least one citation). $27 \%$ of patents are generated by corporate R\&D labs. 


\section{Insert Tables1 and 2 here}

\section{$5 \quad$ Econometric results}

\subsection{The nature of decentralized research}

Table 2 reports the unconditional differences in the means of patents assigned to affiliates and centrally assigned patents. The first column shows that centrally assigned patents receive more citations, cite non-patent references (i.e., cite scientific publications) more frequently, and are more general, than patents assigned to affiliates. We then divide patents into those generated by corporate R\&D labs and others. Although the same pattern of relationships is evident in both samples, the differences between centrally assigned patents and decentralized are smaller in patents that corporate labs produce. For instance, whereas the difference in the average number of citations received between centrally assigned and decentralized patents is 0.23 in patents that corporate labs generate, the difference doubles to 0.49 in patents produced elsewhere (i.e., outside corporate labs). In other words, the nature of the research depends upon where in the organization it is performed as well as for whom it is performed. This is consistent with the interpretation is that patent generated by corporate $\mathrm{R} \& \mathrm{D}$ labs but assigned to affiliates represent a hybrid organization - one where the firm tries to get capture the spillovers from research by coordinating research in labs but also tries to make R\&D more responsive to the needs of its businesses. This interpretation is explored more systematically below.

Table 2 does not control for a variety of firm and industry specific variables. To do so, we estimate a Probit model in which the dependent variable takes value 1 if the patent is assigned to an affiliate (decentralized) and zero otherwise. Note well that we undertake this as a convenient way of capturing the patterns in the data. Put differently, table 2 would have suggested regressing characteristics such as the number of citations, generality and originality on whether the patent is assigned to an affiliate and whether the patent is generated by a corporate lab. Such a regression would have yielded an estimate of the mean conditional on decentralization. Reversing the operation proves to be a more convenient way of summarizing the patterns in the data, but the difference is merely in exposition: The theory developed posits that certain types of research (incremental, short term and product-focused) are more likely to be decentralized, and firms in complex 
industries, and focused firms are more likely to centralize research.

Table 3 reports the estimation results (marginal effects of a Probit model). Here the general pattern of results is consistent with the predictions of all three theories. First, there is a strong positive relationship between discrete technologies and decentralization. We classify our sample patents to 7 main technology areas based on their International Patent Classification code ${ }^{7}$. Discrete technology areas are pharmaceuticals, biotechnology, and chemicals, where complex technologies include telecommunications, electronics, semiconductors, and information technology. As column 1 shows, there is a clear pattern of lower decentralization probability for complex technologies.

Second, our results suggest that patent quality and basicness is negatively related to decentralization. We find that centrally assigned patents tend to receive substantially more citations than decentralized ones. Based on the estimates of column 1, a one standard deviation increase in the number of citations received lowers the probability that a patent is assigned to an affiliate by 6.4 percentage points $(15.9 \times(-0.004))$, or by $35 \%$ percent of the average probability of affiliate assignment. Patent that are assigned to affiliates make fewer citations to non-patent literature than centrally-assigned patents. 106,617 patents make at least one non-patent citations, and $85 \%$ of these patents are centrally assigned. Similarly, centrally assigned patents are more general and more original. Column 2 confirms that these results continue to hold when we exclude those patents that receive no citations from the estimation sample.

Third, column 3 shows a positive effect of technical diversity on decentralization probability, also consistent with Hypothesis 2. Note however that diversity is strongly related to the extent of patenting - firms that patent are lot are also likely to be more focused in their patenting. Thus, we cannot cleanly separate the effect of size from diversity.

As was also suggested in table 2, we find that (compare columns 6 and 7) that the location of $R \& D$ in the organization conditions the foregoing relationships. Patents that do not originate from corporate R\&D labs and are assigned to affiliates (decentralized) receive significantly fewer citations, are less likely to cite non-patent prior art, and are less general and original. However, even patents that are generated by central labs and are assigned to affiliates receive fewer citations compared to patents from central labs that are centrally assigned. Similarly, compared to centrally assigned patents from central labs,

\footnotetext{
${ }^{7}$ Patent that are not classified to any of the main categories are classified under Other.
} 
affiliate assigned patents from central labs are less likely to cite non-patent prior art, and are less general and original.

The remaining specifications show that these patterns are robust. Column 4 controls for additional firm effects by controlling for the share of the firm's patents in each of the 197 major MSAs. Column 2 shows that the patterns hold when we consider only patents that receive citations (about 130,000 patents, or slightly more than a fifth of patents do not receive any citations during the sample period). Column 5 shows that the patterns hold when we restrict the sample of patents to those internally generated by the firm. In unreported estimation we find that these results are robust when we estimate a linear probability model with firm-fixed effects (i.e., a within-firm specification). The inclusion of firm fixed effects raises the $\mathrm{R}^{2}$ substantially, indicating that patent assignment reflects underlying organization structure. However, even with firm fixed effects, the differences in the nature of centralized and decentralized research are similar to those reported in table 3 .

\section{Insert Table 3 here}

\subsection{Implications of decentralization for innovation}

We focus on two measures, R\&D investment and patenting. In contrast to the foregoing analysis, R\&D and patenting are studied at the level of the firm. Although we have multiple observations per firm, as the foregoing results show, the organization of R\&D within a firm is stable over time. Thus, although we include multiple observations per firm, we do not exploit within-firm variation over time in R\&D or patenting.

\subsubsection{R\&D equation}

Table 4 reports the estimation results. Consistent with H3, the results show that decentralization is associated with lower investment in R\&D. Column 1 shows that increasing the share of affiliate assigned patents from 0 to its mean (0.33), is associated with a $10 \%$ reduction in $\mathrm{R} \& \mathrm{D}(0.33 \times 0.30)$. Column 2 shows that the existence of at least one corporate $\mathrm{R} \& \mathrm{D}$ lab is associated with a $17 \%$ increase in $\mathrm{R} \& \mathrm{D}$, but the effect of assignment to affiliates is unchanged. Column 3 shows that increasing the share of lab generated patents has a small and statistically insignificant effect on R\&D, and (comparing to column 4), 
this does not affect the estimated coefficient of the share of affiliate assigned patents. The remaining specifications further explore the robustness of the results. Column 5 shows that the share of patents acquired in M\&A transactions does not condition R\&D investments. Column 6 shows that the results are robust to including the share of the firm's patents in different locations (MSAs), indicating that the effects we are measuring, are not driven by where firms locate their R\&D activities. Columns 7-9 report a very similar pattern for specifications where the dependent variable is $\ln (R \& D /$ Sales $)$. We control throughout for size by using lagged sales, and for industry fixed effects (4 digits SIC) and year dummies. Insofar as assignment is only observed when the firm has distinct affiliates (instead of divisions), we also control for the number of affiliates.

Recall that we have formulated our hypotheses in terms of the patterns of association we expect to observe. The patterns in table 4 are consistent with hypothesis 3 . The existence of a corporate R\&D lab may signal either rich opportunities for technical advancement or the potential for internal spillovers from research. The implication is higher levels of R\&D investment. However, controlling for the existence of such labs, greater decentralization is associated with lower R\&D investments. This may reflect under-investment by units that research projects that bring limited benefits to them but with beneficial spillovers to other parts of the firm.

\section{Insert Table 4 here}

\subsubsection{Patent equation}

We next investigate the patent equation using the flow of patents produced per firm- per year and an equivalent specification for the flow of patents divided by R\&D stock. ${ }^{8}$ Columns 1-5 in Table 5 report the estimation results for the annual flow of patents. (in logs). Column 1 shows a negative and significant relationship between the share of patents assigned to affiliates and patent propensity. The coefficient of share affiliate assigned patents is -0.16 , implying that an increase this share from 0 to the mean level is associated with a reduction in patenting of about 5\%. As with the R\&D equation, controlling for whether there is a corporate $\mathrm{R} \& \mathrm{D}$ lab is positive and significant - a lab is associated with an increase of about $20 \%$ in patenting - consistent with the idea that the presence of a lab

\footnotetext{
${ }^{8}$ All results are robust to alternative specifications, such as Negative Binomial for patents counts.
} 
signals rich opportunities for technical advance. Once again, the estimated coefficient on patents assigned to affiliates is similar in size and significance whether we control for the presence of a corporate R\&D lab or not. As Column 2 also shows, the estimated coefficient of the share of patents generated from labs is both small and statistically insignificant. In all these specifications, we control for industry effects (4 digit SIC), and year effects, along with size (lagged sales, in logs), R\&D stock (lagged by a year), and by the number of affiliates.

This pattern is robust to controlling for patents acquired through M\&A (Column 3), controlling for the location of the firm's R\&D activities (controls for MSA in Column 4) or weighting patents by citations (Column 5). Columns 6-9 report the equivalent specifications flow of patent, divided by R\&D Stock. Column 5 shows a negative and significant relationship between decentralization and patent propensity, similarly robust to location controls and controls for M\&A patents (Column 8) and weighting patents by citations. The coefficient on share decentralized is -0.187 , which implies that increasing this share from zero to the mean level is associated with a reduction in patents per dollar of R\&D by about $6 \%$. This may appear to be a small effect but recall that decentralized $\mathrm{R} \& \mathrm{D}$ is associated with lower $\mathrm{R} \& \mathrm{D}$ investments. Insofar as there are diminishing returns to $R \& D$, a reduction in $R \& D$ should have resulted in an increase in patenting per $R \& D$ dollar. Put differently, the effect of decentralization on the propensity to patenting inventions is likely larger than the estimated 5-6\%.

In contrast to the results on the nature of decentralized research, $R \& D$ and patenting behavior seems to be more sensitive to the assignment of patents to affiliates rather than to the share of patents generated from corporate labs. This is consistent with our interpretation that, roughly speaking, assignment is measuring who (in the organization) is paying for the corresponding $\mathrm{R} \& \mathrm{D}$, rather than who (or where in the organization) the $\mathrm{R} \& \mathrm{D}$ is being performed. Characteristics of research, however, depended both on who pays for the $\mathrm{R} \& \mathrm{D}$ as well as where the $\mathrm{R} \& \mathrm{D}$ is being performed, as evidenced by table 3 .

\section{Insert Table 5 here}




\subsection{Implications of decentralization for market value and growth}

\subsubsection{Market value}

Hypothesis 4 posits mixed results for the impact of centralization on market value, which depend on the nature of R\&D, and whether or not spillovers are likely. More clearly, it posits that the marginal value of decentralized $R \& D$ will be greater. To this end, we estimate a simple version of the value function approach proposed by Griliches $(1981)^{9}$. The interpretation of a market value regression is not straightforward. The one we follow here is that this is the value placed upon the stock of the various assets of the firm. Once again, we do not exploit within-firm variation over time because the organization of $R \& D$ within a firm varies very little over time.

Table 6 reports the estimation results for the market value equation. The reported standard errors are robust to arbitrary heteroskedasticity and allow for serial correlation within firms. We include controls for number of affiliates, assets, R\&D stock and the total stock of patents. Column 1 reports coefficient on the share of patents that are assigned to affiliates. 0.245 , implying that increasing the share from zero to its mean value of 0.33 would be associated with an increase in market value of about $8.5 \%$. The coefficient on overall patents stock is positive and significant as well, with an estimated elasticity of about 5\%. ${ }^{10}$ In column 2 we add controls for share of corporate lab-originated patents and a dummy for whether the firm had at least one central lab. Once again, having at least one corporate lab is associated with an increase in value of about 14\%, perhaps signaling the value placed by investors on the technical opportunities the firm enjoys. The share of lab generated patents, however, is negative, implying that decreasing this share from its mean of 0.27 to 0 would be associated with an increase in value of about $2.5 \%$. These results are consistent with the mixed implications of the theory developed in which no

\footnotetext{
${ }^{9}$ See also Jaffe (1986), Hall et al (2005) or Lanjouw and Schankerman (2004).

${ }^{10} \mathrm{In}$ unreported specifications, we include a set of three separate indicator variables that capture the non-linear effect of decentralization. For each firm we assign a value of 1 to only one of these dummy variables based on which pattern best describes the firm's patents: all patents are centrally assigned (share decentralized is zero); share decentralized is between zero and 0.2 ; share decentralized is between 0.2 and 0.8 ; share decentralized is above 0.8. Using the zero-share decentralization subset as our base category, we find that the value-decentralization relationship is driven mostly by firms where at least $20 \%$ of their patents are decentralized. The coefficient on dummy for zero to 0.2 decentralization share is not statistically significant (a coefficient of 0.110 and a standard error 0.068). The coefficient on dummy for decentralization share higher than 0.8 is 0.173 (a standard error of 0.063 ), while the coefficient estimate for 0.2-0.8 decentralization range is 0.256 (a standard error of 0.068).
} 
organizational form universally dominates the other. They are, however, consistent with the specific prediction that the marginal decentralized project creates value whereas the marginal centralized project merely covers its cost (and perhaps destroys value insofar as it reflects the scientific interests of the firm's researchers rather than the economic interests of the firm). As a comparison between Columns 1, 2 and 3 shows, these results are not sensitive to whether we include both measures of decentralization (assignment and lab generated patents) or each measure individually. Similarly, these results are not sensitive to controlling for the location of the firm's R\&D activities, as was also the case for R\&D and patenting. However, Column 4 shows that, unlike the case for R\&D and patenting, patents acquired through M\&A are part of the reason that patents assigned to affiliates are associated with higher market values. This suggests decentralization may have other benefits, such as the ability to access external R\&D.

Recall that we had interpreted the share of patents assigned to affiliates as measuring who pays for the R\&D project and the share of lab generated patents as measuring who performed the research. Thus, we interpret a corporate lab generated patent is assigned to an affiliate as reflecting the situation where the R\&D project is funded (and likely also chosen) by an affiliate but executed by a central R\&D lab. This "hybrid" organization of R\&D could be expected to ameliorate the lack of coordination and neglect of spillovers characteristic of decentralized R\&D, while not losing the connection to business needs that may afflict centralized R\&D. Column 8 reports the results of a specification where we divide lab generated patents into those that are assigned to affiliates and those that are centrally assigned. Whereas centrally assigned patents generated from labs have a negative coefficient of -0.09 (with a standard error of 0.04 ), lab generated patents that are assigned to affiliates have a positive and statistically significant coefficient. To explore this distinction further, we split the sample into firms with at least one corporate R\&D lab and those without. Comparing Columns 6 and 7, we see that assignment to affiliates is more strongly associated with value in firms with a corporate $\mathrm{R} \& \mathrm{D}$ lab than in firms without a lab. The coefficient on assigned patents is nearly 0.4 , more than three times in size for firms with a corporate R\&D lab than for firms without such labs. Columns 9 and 10 show similar results when estimating Tobin's Q specification, namely that assignment to affiliates is positively associated with market value, especially for lab generated 
patents. $^{11}$

\section{Insert Table 6 here}

\subsubsection{Sales growth}

We proceed to explore the impact of decentralization of $R \& D$ on firm sales growth. Though we had not formulated an explicit hypothesis on sales growth, the discussion had strongly suggested that decentralization should be associated with higher sales growth for two reasons. First, decentralized R\&D would support existing products and services, improving sales. Second, unit managers enjoying greater focus by autonomy (including autonomy on R\&D and IP management) would be able to engage in "division building" for instance by rejecting licensing opportunities that would create value for the company but hurt their own sales. More generally, such managers would be able to restrict R\&D projects that threaten to cannibalize sales of their existing products, a strategy that might be harmful in the long run (a conjecture not supported by the foregoing $R \& D$ regressions), but would certainly produce higher sales growth. in the short run.

Table 7 reports the estimation results. In all specifications, we report standard errors robust to arbitrary heteroscadisticity and clustered at the firm level to allow for correlation in errors within a firm. As well, we control for size (assets and sales), R\&D stock, and the stock of patents (all lagged), and industry (4 digit SIC) and year effects Columns 1 examines the decentralization-growth relationship. Consistent with our findings for market value, the coefficient on share decentralized is positive and is highly significant (0.037 and a standard error of 0.010).), implying that. increasing the share from zero to the mean value would be associated with an increase in growth by about 1 percentage point. In

\footnotetext{
${ }^{11}$ We check the robustness of our findings to changes in patent assignment over time. We determine whether a patent is assigned to an affiliates or headquarters by examining the assignee name that appears on the patent document when it was granted. However, assignees can change over the patent life-cycle. Reasons for reassigning a patent include a merger or an acquisition, or a managerial decision within-firms of how to allocate IP assets across the organization units. Using data on reassignments, as coded by the USPTO, we test the robustness of our key results. 41,244 patents in our sample are reassigned. Close to $90 \%$ of these reassignments are assigning a patent from headquarters to an affiliate (36,180 patents). There is no big difference in the share of reassigned patents between M\&A and internal patents. For M\&A patents, $8 \%$ are reassigned (8,410 patents), where for internal patents, $7 \%$ are reassigned $(32,834$ patents). For M\&A-related reassignments, $23 \%$ are reassignments from affiliates to headquarters, where for internal patents, about $91 \%$ of reassignments are from headquarters to affiliates.

We repeat our estimations by accounting for changes in reassignments. The same pattern of results continue to hold, with no significant change in the main coefficient estimates.
} 
column 2 we include controls for share of central lab-originated patents and a dummy for whether the firm had at least one central lab. The coefficient on share of assigned patents is identical after adding these controls. Whereas the existence of a corporate lab is associated with higher growth, , the share of lab generated patents has a negative coefficient, about a third in size of the coefficient of affiliate-assigned patents.,. As with market value and different from $R \& D$ and patenting, patents acquired through M\&A are positively associated with firm growth (Column 3). Introducing the controls for inventor location (Column 4) reduces the coefficient on the share of lab patents from -.013 (1\% significance) to -.006 with no statistical significance. Possibly, this is because our control for location is the share of the firm's patent in each MSA, which may be highly correlated with the share of the firm's patents produced by its corporate R\&D labs.

Comparing Columns 5 and 6, we see that assignment to affiliates has a much stronger association with sales growth in firms that have corporate R\&D labs compared to firms that do not have such labs. Taken in conjunction with the positive association between sales growth and the existence of such labs, we conclude, similar to the discussion with market value, that this hybrid form seems to provide a useful via media between the two extreme organizational forms of pure centralization and pure decentralization.

\section{Insert Table 7 here}

\section{Conclusion and suggestions for future research}

This paper develops a new way of using patent data to measure the organization of $R \& D$ within firms, and explores the relationship between firm organization and the extent and nature of research activity, as well its association with performance as measured in sales growth and market value.

We use data 1,290 American publicly-listed corporations, with 2,615 Patent-receiving affiliates, as well as characteristics of 594,903 patents that belong to these corporations. One of our key measure is whether a patent is assigned to the parent corporation or to an affiliate. The assignment of intellectual property to a wholly owned affiliate cannot have legal significance. However, it likely reflects a de facto delegation of authority to the affiliate in how the R\&D is managed, a suggestion which is supported by our interviews 
with managers. This interpretation is also consistent with the very high share of patents generated by corporate $\mathrm{R} \& \mathrm{D}$ labs, typically part of the central $\mathrm{R} \& \mathrm{D}$ organization in large firms, assigned to the parent firm rather than to affiliates.

We find that patents assigned to affiliates are less likely to cite scientific papers, less general in scope, and receive fewer citations, especially when these patents are not generated in corporate R\&D labs. Firms that extensively decentralize patents are more likely to rely upon mergers and acquisitions to acquire patents, and likely to be more diversified.

We next turn to the relationship between decentralization and outcomes. We find that firms that decentralize $R \& D$ invest less in $R \& D$, and given their $R \& D$ investment, produce fewer patents. The may reflect the efficacy of decentralized R\&D, or the more incremental nature of decentralized R\&D, or merely difference in incentives to patent. However, despite being associated with lower investments in $R \& D$ and patents, decentralized $R \& D$ is associated with higher market value and sales growth, suggesting that whereas centralized research may be technically and scientifically superior, the private economic benefits are less clear cut.

Given that the nature of research and the choice of organizational forms are jointly determined, and related to unobserved factors such as technological opportunities, one cannot infer causal impacts of organizational form on performance. For instance, the data strongly suggest that the existence of a corporate $R \& D$ lab is associated with higher $R \& D$ and patenting, but also with higher market value and sales growth.

Nonetheless, the results are informative about the factors that condition the organization of R\&D. Our findings are consistent with a view that decentralized $R \& D$, though more attentive to the immediate needs of the business, is also less likely to result in fundamental advances in technology. Conversely, centralized R\&D, though perhaps better for managing pioneering research that draws upon scientific advances, is susceptible to wasteful expenditures on scientifically interesting projects with limited value for the firm. Consistent with this, our findings also suggest that hybrid organizations, where R\&D is performed centrally but the projects are those that the individual units and affiliates are willing to pay for, may be a useful compromise between the two pure forms. Over and above these findings, this project contributes by revealing a new way of using patent data to proxy for differences in organizational structure.

Future research should focus on teasing out some of the specific mechanisms through 
which the different relationships documented in this paper operate. We outline some potentially promising starting points. First, we find a negative relationship between firm's market value and centralization. One mechanism that can drive this relationship is capture by corporate scientists, who may value "pro-publication" incentives (Merton, 1973). As Cockburn, Henderson \& Stern have argued, these scientists may derive pecuniary benefits(e.g. promotion)and non-pecuniary benefits (e.g. reputation) form increasing their public rank within their peer hierarchy. This may skew the focus of their R\&D activities towards increasing these private benefits, possibly at the expense of enhancing shareholder value. Interestingly, Cockburn, et.al. suggest that this mechanism may be potentially beneficial to the firm, given that these costly pro-publication organizational arrangements may be seen as the "ticket of admission" which increases firms absorptive capacity (Cohen \& Levinthal, 1990), and thus "pays itself off in terms of higher R\&D productivity." Our data suggest that on average this is an investment that may not pay off, or may exhibit diminishing returns. Future empirical work should test this mechanism more directly, for example, by incorporating firm publications data and confirming whether corporations that publish more of their research output in leading academic journals are indeed more likely to be centralized, and capture on average lower market returns on their R\&D investments.

Second, if decentralization adds value by allowing divisions to better exploit local information (Jensen and Meckling, 1992), and minimize delay that is associated with transmission of information to corporate headquarters (Radner, 1993); (Van Zandt 1999), we would expect this benefit to be especially strong in higher-velocity environments (Bourgeois \& Eisenhardt, 1988)such as more dynamic and complex industries, and less valuable in static and discrete ones, where presumably responding fast to new information plays a less important rule. Here, the variation between industries, as well as firm's responses to sharp and discontinuous environmental changes could be exploited to assess the relative value of decentralization. Closely related to this is the dimension of local information which stems from geography. One may expect firms to vary in the extent to which local information is geographically dispersed. If decentralized firms are less geographically concentrated, one could test whether the value-decentralization relationship is stronger for firms that operate in more geographically dispersed markets.

A separate mechanism is the management of mergers and acquisitions (e.g. target 
selection and post-merger integration). A substantial variation in our data is the extent to which acquired new firms are kept independent, rather than being subsumed and integrated into the parent organization. The patterns of assignment of patents to and from headquarters following acquisitions suggests that deliberate decisions drive this allocation of rights, and future works should look more closely at the decision of firms to keep acquired affiliates independent. The mechanisms mentioned above should play an important part in this analysis. For example, scientist-intensive companies may be biased towards full integration. Similarly, they may benefit from acquiring firms with more "basic" technologies that are further away from commercialization. Along these lines, an interesting interpretation of the patterns we find in this paper is that some firms may favor structures which reduce the transaction costs associated with the buying and selling other firms. That is, headquarters may develop capabilities in acquiring businesses where part of the value may come from an eventual disposition. To the extent that the typical goal is to ultimately sell the units they invest in, these firms may face a trade-off between maximizing synergies and spillovers during the hold period, versus increasing flexibility to divest later. Future research should investigate the extent to which a decentralized structure allows firms to more easily and effectively divest divisions. The intuition here is that keeping IP from commingling with headquarters by maintain the assigning of patents to units may make future divestitures more efficient. This may make the unit's IP assets more clearly defined, so that they do not have to be negotiated over during a sale transaction.

A separate issue that we have not explored, but can be potentially important, is the notion that assignment of intellectual property rights to affiliates has a causal effect on performance. The are several reasons to suspect the presence of this causal effect. Consistent with the property rights theory of the firm (Grossman \& O. D. Hart, 1986; O. Hart \& Moore, 1990), assigning ownership rights may have a real and substantial effect of incentives, and thus behavior in both ex-ante R\&D investment decisions, and ex-post commercialization strategies. While assignment of IP within the organization does not have a clear legal interpretation, it may still affect incentives through more subtle mechanisms, such as pride of ownership (Estrin, Jones, \& Svejnar, 1987) and relational contracting (Baker, Gibbons, \& Murphy, 2002). Moreover, assigning IP to affiliates may be important from a contracting standpoint. Divisions, unlike affiliates, cannot independently contract with outsiders. IP assignment to affiliates may reduce the cost of technology 
transactions by allowing outsiders to directly interact with the relevant unit, rather with the entire corporation headquarters. Testing the causal effect of assignment is indeed a substantial challenge. A stating point could be to distinguish between specialized and diversified corporations. Presumably, specialized corporations are associated with greater intra-organization transactions between units and more frequent reallocation of resources. We would expect that in these organizations the incentives benefits associated with assignment would play a more important role than in diversified organizations where boundaries between the IP of different units in the organizations are more clearly defined. Additional tests could look at industry profitability shocks as exogenous triggers to resources reallocation. The assignment hypothesis would then predict that units that own the IP they generate would be less sensitive to shocks affecting the organization as a whole, than units where IP is controlled by headquarters.

We hope that future research could shed light on these central mechanisms. 


\section{References}

[1] Acemoglu, D., P. Aghion, C. Lelarge, J. Van Reenen, and F. Zilibotti. 2007. "Technology, Information and the Decentralization of the Firm." Quarterly Journal of Economics 122, 1759-1800.

[2] Agarwal, R., M. Ganco, and R.H. Ziedonis. 2009. "Reputations for toughness in patent enforcement: Implications for knowledge spillovers via inventor mobility." Strategic Management Journal 30: 1349-1374.

[3] Aghion, P. and J. Tirole. 1997. "Formal and real authority in organizations." Journal of Political Economy 105, 1-29.

[4] Alcácer, Juan. 2006. "Location Choices Across the Value Chain: How Activity and Capability Influence Collocation." Management Science 52(10): 1457-1471

[5] Almeida, P, and Kogut, B. 1999. "Localization of Mobility of Engineers Knowledge in Regional and the Networks." Management Science 45(7): 905-917.

[6] Alonso, R., W. Dessein, and N. Matouschek. 2008. "When Does Coordination Require Centralization?." The American Economic Review 98, 145-179.

[7] Alonso, R., W. Dessein, and N. Matouschek. 2008. "Centralization versus Decentralization: An Application to Price Setting by a Multi-market Firm." Journal of the European Economic Association 6, 457-467.

[8] Argyres, N. S., and B. S. Silverman. 2004. "R\&D, organization structure, and the development of corporate technological knowledge." Strategic Management Journal 25(89): 929-958.

[9] Arora, A., Fosfuri, A., and Gambardella, A., 2001. "Markets for Technology and their Implications for Corporate Strategy." Industrial and Corporate Change 10(2): 419-451.

[10] Arrow, K. 1962. "Economic Welfare and the Allocation of Resources of Inventions." In The Rate and Direction of Inventive Activity, Princeton, NJ: Princeton University Press. 
[11] Baker, G. and T. Hubbard. 2003. "Make Versus Buy in Trucking:Asset Ownership, Job Design, and Information." American Economic Review 93, 551-572.

[12] Baker, G., R., Gibbons, and K.J. Murphy. 1999. "Informal authority in organizations." Journal of Law, Economics, and Organization 15(1): 56.

[13] Baker, G. and T. Hubbard. 2004. "Contractibility And Asset Ownership: On-Board Computers and Governance In U. S. Trucking." Quarterly Journal of Economics 119, 1443-1479.

[14] Baker, G., R. Gibbons, and K. Murphy. 2002. "Relational Contracts and the Theory of the Firm." Quarterly Journal of Economics 117, 39-84.

[15] Belenzon, S., T. Berkovitz, and P. Bolton. 2010. "Intracompany Governance and Innovation." Working Paper.

[16] Belenzon, S. and A. Patacconi. 2010. "Firm Size and Innovation: Evidence from European Panel Data." Working Paper.

[17] Bhaskarabhatla, A., A Note on IBM's Defensive Publications 1958-1998, Unpublished 2010

[18] Bloom, N., R. Sadun, and J. Van Reenen. 2008. "Measuring and explaining decentralization across firms and countries." Working Paper.

[19] Bolton, P. and M. Dewatripont. 1994. "The Firm as a Communication Network." The Quarterly Journal of Economics 109, 809-839.

[20] Bradley, S.W., H. Aldrich, 2010. "Resources, Environmental Change, and Survival: Asymmetric Paths of Young Independent and Subsidiary Organizations." Strategic Management Journal (September 2008).

[21] Bresnahan, T., E. Brynjolfsson, and L. Hitt. 2002. "Information Technology, Workplace Organization, and the Demand for Skilled Labor: Firm-Level Evidence." Quarterly Journal of Economics 117, 339-376.

[22] 419-451. Available at: http://icc.oupjournals.org/cgi/doi/10.1093/icc/10.2.419. 
[23] Brusoni, S., Prencipe, A., and Pavitt, K., 2001. "Knowledge Organizational Coupling , and the Boundaries of the Firm : Why Do Firms Know More Than They Make ?" Administrative Science Quarterly.

[24] Bourgeois, L. J., \& Eisenhardt, K. M. 1988. Strategic Decision Processes in High Velocity Environments: Four Cases in the Microcomputer Industry. Management Science, 34(7), 816-835. doi: 10.1287/mnsc.34.7.816.

[25] Caroli, E. and J. Van Reenen. 2001. "Skill-Biased Organizational Change? Evidence from a Panel of British and French Establishments." Quarterly Journal of Economics 116, 1449-1492.

[26] Casciaro, T., and Piskorski, M.J. 2005. "Power imbalance, mutual dependence, and constraint absorption: A closer look at resource dependence theory." Administrative Science Quarterly 50(2): 167-199

[27] Chandler, A. 1977. The Visible Hand: the Managerial Revolution in American Business, Harvard University Press, 1977.

[28] Child, J. (1984). New technology and developments in management organization. Omega International Journal of Management Science, 12(3), 211-223.

[29] Cockburn, I., Henderson, R., and Stern, S., 1999. "The diffusion of science driven drug discovery: organizational change in pharmaceutical research." NBER Working Papers Series.

[30] Cohen, W.M., and Levinthal, D.A. 1990. "Absorptive capacity: a new perspective on learning and innovation." Administrative science quarterly 35(1): 140-155.

[31] Colombo, M. and M. Delmastro. 2004. "Delegation of Authority In Business Organizations: An Empirical Test." Journal of Industrial Economics 52, 2004, 53-80.

[32] DeSanctis, G., and J.T. Glass and I.M. Ensing. 2002. "Organizaional Design for R\&D." Academy of Management Executive 16(3).

[33] Dessein, W. 2002. "Authority and communication in organizations." Review of Economic Studies 69, 811-838. 
[34] Estrin, S., D. Jones, and J. Svejnar. 1987. "The Productivity Effects of Worker Participation: Producer Cooperatives in Western Economies." Journal of Comparative Economics 11, 40-61.

[35] Feinberg, S. E., and A.K. Gupta. 2004. "Knowledge spillovers and the assignment of R\&D responsibilities to foreign subsidiaries." Strategic Management Journal 25(89): 823-845.

[36] Furman, J.L. 2003. "Location and organizing strategy: Exploring the influence of location on the organization of pharmaceutical research." Advances in Strategic Management 20: 49-88.

[37] Galunic, D. C., and K. M. Eisenhardt. 2001. "Architectural Innovation and Modular Corporate Forms." The Academy of Management Journal 44(6): 1229.

[38] Ghemawat, P. 1987. "Investment in lumpy capacity." Journal of Economic Behavior \& Organization 8(2): 265-277.

[39] Grossman, S. J., and O. D. Hart. 1986. "The Costs and Benefits of Ownership: A Theory of Vertical and Lateral Integration." Journal of Political Economy 94(4): 691

[40] Griliches, Z. 1990. "Patent Statistics as Economic Indicators: A Survey." Journal of Economic Literature 28, 1661-1707.

[41] Gupta A. and V. Govindarajan. 2000. "Knowledge flows within multinational corporations." Strategic Management Journal 496, 473-496.

[42] Hall, B., A. Jaffe, and M. Trajtenberg. 2005. "Market Value and Patent Citations." The RAND Journal of Economics 36, 16-38.

[43] Hall, B. and R. Ziedonis. 2001. "The Determinants of Patenting in the U.S. Semiconductor Industry, 1980-1994." Rand Journal of Economics 32, 101-128.

[44] Hannan, M.T., and J. Freeman. 1984. "Structural inertia and organizational change." American sociological review 49(2): 149-164.

[45] Hart, O. and J. Moore. 1990. "Property Rights and the Nature of the Firm." Journal of Political Economy 98, 1119- 1158. 
[46] Jaffe, A. 1986. "Technological Opportunity and Spillovers of R \& D: Evidence from Firms' Patents, Profits, and Market Value." The American Economic Review 76, 984-1001.

[47] Henderson, R., and K. Clark. 1990. "Architectural innovation: the reconfiguration of existing product technologies and the failure of established firms." Administrative science quarterly.

[48] Henderson, R, and I Cockburn. 1996. "Scale, scope, and spillovers: the determinants of research productivity in drug discovery." The Rand journal of economics 27(1): $32-59$.

[49] Hill, S., R. Martin, and M. Harris. 2000. "Decentralization, Integration and the PostBureaucratic Organization: The Case of R\&d." Journal of Management Studies 37(4): 563-586.

[50] Hitt, M., and R. Hoskisson, 1990. "Mergers and acquisitions and managerial commitment to innovation in M-form firms." Strategic Management 11: 29-47.

[51] Hounshell, D.A., and Smith, J.R., "Science and Corporate Strategy: Du Pont R\&D 1902-1980." Cambridge University Press, Cambridge, 1988

[52] Jaffe, A.B., M. Trajtenberg, and R. Henderson. 1993. "Geographic localization of knowledge spillovers as evidenced by patent citations." The Quarterly journal of Economics 108(3): 577-598.

[53] Jensen, M. C. 1999. "Agency Cost Of Free Cash Flow, Corporate Finance, and Takeovers." SSRN Electronic Journal 76(2): 323-329

[54] Jensen, M. C., and W. H. Meckling. 1992. "Specific and General Knowledge and Organizational Structure." In Contract Economics, eds. L. Werin and H. Wijkander. Oxford: Blackwell Publishing, p. 251-274.

[55] Kanter. R. 1985. "Supporting innovation and venture development in established companies." Journal of Business Venturing 1, 47-60.

[56] Kastl, J. D. Martimort, and S. Piccolo. 2009. "Delegation and R\&D Spending: Evidence from Italy." Working Paper. 
[57] Kay, N. 1988. "The R\&D function: corporate strategy and structure." In Technical Change and Economic Theory, eds. G. Dosi et al. London.

[58] Kline, S.J., and N. Rosenberg. 1986. "An overview of Innovation." In The Positive Sum Strategy: Harnessing Technology for Economic Growth, National Academy of Sciences, p. 275-305.

[59] Kogut, B. 1991. "Country capabilities and the permeability of borders." Strategic Management Journal 12(S1): 33-47.

[60] Lahiri, N. 2010. GEOGRAPHIC DISTRIBUTION OF R \& D ACTIVITY : HOW DOES IT AFFECT INNOVATION QUALITY? Academy of Management Journal, 53(5), 1194-1209.

[61] Lerner, J., and J. Wulf. 2007. "Innovation and Incentives: Evidence from Corporate R\&D." Review of Economics and Statistics 89(4): 634-644.

[62] Leiponen, A., and C. E. Helfat. 2010. "Location, Decentralization, and Knowledge Sources for Innovation." Organization Science: 1-18.

[63] Mowery, David C, Joanne E Oxley, and Brian S Silverman. 1996. "Strategic alliances and inter-firm knowledge transfer." Strategic Management Journal 17: 77-91.

[64] Matouschek, N. and P. Ramezzana. 2007. "The Role of Exclusive Contracts in Facilitating Market Transactions." The Journal of Industrial Economics 55, 347-371.

[65] Mintzberg, H. (1979). The Structuring of Organizations. Englewood Cliffs (p. 512). Prentice-Hall.

[66] Mookherjee, D. and M. Tsumagari. 2004. "The organization of supplier networks: effects of delegation and intermediation." Econometrica 72, 1179-1219.

[67] Nelson, R.R., and S.G. Winter. 1982. Wn Evolutionary Theory of Economic Change. Cambridge: Harvard University Press.

[68] Nobel, R., and J. Birkinshaw. 1998. "Innovation in multinational corporations: control and communication patterns in international R\&D operations." Strategic Management Journal 19(5): 479-496. 
[69] Patacconi, A. 2009. "Coordination and delay in hierarchies." The RAND Journal of Economics 40, 190-208.

[70] Penner-Hahn, J., and J. M. Shaver. 2005. "Does international research and development increase patent output? An analysis of Japanese pharmaceutical firms." Strategic Management Journal 26(2): 121-140.

[71] Podolny, J. M., and J. N. Baron. 1997. "Resources and Relationships: Social Networks and Mobility in the Workplace." American Sociological Review 62(5): 673.

[72] Radner, R. 1993. "The organization of decentralized information processing." Econometrica 61, 1109-1146.

[73] Radner, R. and J. Marschack. 1972. Economic Theory of Teams, New Haven: Yale University Press.

[74] Reagans, Ray, and E.W. Zuckerman. 2001. "Networks, diversity, and productivity: The social capital of corporate R\&D teams." Organization Science 12(4): 502-517.

[75] Reger, G.. 1999. "How R\&D is coordinated in Japanese and European multinationals." R \& D Management 29(1): 71-88.

[76] Riordan, M. 2008. "Competitive effects of vertical integration." Handbook of Antitrust Economics, 145-82.

[77] Roberts, P. W., and S. McEvily. 2004. "Product-line expansion and resource cannibalization." Journal of Economic Behavior \& Organization 57(1): 49-70.

[78] Rosenkopf, L., and P. Almeida. 2003. "Overcoming local search through alliances and mobility." Management Science 49(6): 751-766.

[79] Rotemberg, J. and G. Saloner. 1994. "Benefits of Narrow Business Strategies." The American Economic Review 84, 1330-1349.

[80] Siggelkow, N., and D.A. Levinthal. 2003. "Temporarily divide to conquer: Centralized, decentralized, and reintegrated organizational approaches to exploration and adaptation." Organization Science 14(6): 650-669. 
[81] Siggelkow, N., and J. W. Rivkin. 2006. "When Exploration Backfires: Unintended Consequences of Multilevel Organizational Search." The Academy of Management Journal 49(4): 779 .

[82] Singh, J., 2008. "Distributed R\&D, cross-regional knowledge integration and quality of innovative output." Research Policy 37(1): 77-96.

[83] Szulanski, G. 2009. "Exploring Internal Stickiness: Impediments to the Transfer of Best Practice Within the Firm." Strategic Management Journal 17, pp. 27-43.

[84] Teece, D. 1996. "Firm organization, industrial structure, and technological innovation." Journal of Economic Behavior 83 Organization 31, 193-224.

[85] Van Zandt, T. 1999. Decentralized information processing in the theory of organizations. IEA CONFERENCE VOLUME SERIES (Vol. 124, p. 125-160).

[86] Von Hippel, E. 1998. "Economics of product development by users: The impact of" sticky" local information." Management science 44(5): 629-644.

[87] Williamson, O. E. 1975. Markets and Hierarchies: Analysis and antitrust implications. New York: Free Press. 


\section{A Appendix}

This section details the construction of the data platform used in this project. The central datasets consist of a patent-level panel and a firm-level panel, which are linked via the unique patent id numbers. Each of these panels is built up iteratively, by incorporating data from the following sources: (i) patent level information from the United States Patent and Trademark Office (USPTO), (ii) ownership structure data from Icarus and Amadeus by Bureau Van Dyke (BVD), (iii) Merger and acquisition data from Thomson Reuters SDC Platinum and Zephyr by Bureau Van Dyke, (iv) accounting information from U.S. Compustat, and (v) extensive manual searches of on-line resources, such as corporate and governments websites, and search engines.

\section{A.1 Ownership Structure}

Assignee information is available from the USPTO, but many of the patent assignments are made to affiliate firms. Furthermore, firms vary in their choice to utilize affiliates for their assignments, resulting in noisy (at best) or biased (likely) patent and citation counts at the firm level. The linchpin of this project is the identification of an ultimate owner ("UO") for a large portion of the companies reported as patent assignees by the USPTO. Here we follow the methodology employed by Belenzon and Berkowitz (2010). We obtain ownership structure data from the Icarus and Amadeus databases by Bureau Van Dyke (BVD). The Amadeus ownership database includes detailed information of the percentage of ownership between shareholders and their subsidiaries. We develop an ownership algorithm that constructs the internal structure parent and affiliate groupings based on their inter-company ownership links.

The algorithm follows three steps: (i) completes missing ownership links, (ii) generates lists of all subsidiaries and parents for each company, and (iii) constructs the ownership chains bottom-up. To illustrate our methodology, it would be useful to consider the following example. Suppose Figure A.1 correctly describes the ownership structure of a conglomerate. The ultimate owner firm at the apex of the group controls 7 public and private firms. Amadeus provides detailed data on direct ownership links. Thus, our raw data include the links $A \rightarrow D, B \rightarrow F, C \rightarrow G$, and $D \rightarrow E$. Note that the percentage of ownership for the link $C \rightarrow G$ has to be larger than 20 (because firm $G$ is public), where for the percentage of ownership for all other links has to be larger than 50 (because the other subsidiaries are private). Because there is no information about indirect ownership links, the link $A \rightarrow E$ is missing from the raw data. The first step of the algorithm is to complete missing links. As we observe the ownership relations $A \rightarrow D$ and $D \rightarrow E$, our algorithm infers the ownership relation $A \rightarrow E$. Note that at this stage of the algorithm we still do not know whether the ownership relation is direct or indirect (and if it is indirect, how many layers separate firm $E$ from firm $A$ ). The second step of the algorithm is to construct two lists for each firm: shareholders and subsidiaries. This step saves valuable running time, which is especially important when dealing with large scale ownership data. The following table is generated: 


\begin{tabular}{c|c|c}
\hline Firm & Shareholder & Subsidiary \\
\hline \hline$A$ & - & $D, E$ \\
$B$ & - & $F$ \\
$C$ & - & $G$ \\
$D$ & $A$ & $E$ \\
$E$ & $A, D$ & - \\
$F$ & $B$ & - \\
$G$ & $C$ & - \\
\hline
\end{tabular}

Note that from step 1 , we already know that firm $A$ is a shareholder of firm $E$. The third and final step of the algorithm is to construct the structure of the group based on the above ownership relations. Because of the missing links problem, our algorithm does not assume that an ownership relation is direct; the only input the algorithm receives is the existence of the ownership relation. We start with a firm that has no subsidiaries from the list generated in step 2. We illustrate the procedure for firm $E$, which is the most interesting in this example. Firm $E$ is placed at the bottom of the ownership chain. Next, we move to the shareholder list of firm $E$. It includes firms $A$ and $D$. Starting arbitrary with $A$, place $A$ above $E$. Proceeding to firm $D$, there are three possibilities for its location: (i) $D$ is above $E$ and above $A$; (ii) $D$ is above $E$, but below $A$; (iii) $D$ is above $E$, but not below neither above $A$ (different ownership chain). For (i) to be the right structure, $D$ has to appear in the shareholder list of firm $A$. From step 2, we rule this out. For (ii) to be the right structure, $D$ has to appear on the subsidiary list of firm $A$. From step 2, we rule this out. For (ii) to be the right structure, $\mathrm{D}$ has to appear on the subsidiary list of firm A. From step 2, this holds. Finally, for (iii) to be the right structure, A cannot appear on either the shareholder or subsidiary lists of firm D. From step 2, this is ruled out. At the end of this procedure, we have determined for each ownership chain the highest shareholder firm - we call this firm the leading shareholder.

\section{A.1.1 Dealing with M\&A}

A central issue in our analysis is the post-merger management of acquired firms. The decentralization variation in our data comes mostly from two sources: the degree of postacquisition integration of affiliates (with a lower bound being those kept independent), and the speed at which patents are generated centrally in relation to existing affiliates. For each acquired firm we determine whether it remained independent post-acquisition, or whether it was dissolved. We take several steps in determining whether a firm is independent. First, we check whether the firm appears in Amadeus or Icarus as an independent company. Second, we manually check each company listed in the first step whether it continues to operate independently from the parent company. We check their corporate websites to confirm that their legal disclaimers and investor relations information references a parent company.

Dissolved acquisitions are much more problematic. Because we match patents to firms based on the 2008 ownership structure, we lose historical acquisitions that were fully integrated in the parent company and ceased to exist as separate legal entities. Though we do capture post-acquisition patents as those are likely to be assigned to headquarters, we may nonetheless over measure decentralization (because all historical patents that we 
do not match are centralized). To mitigate this problem we take two steps. We match all firms in SDC Platinum where the acquiring firm appears in our sample. We then add to our data all patents that belong to acquired firms that no longer appear in the 2008 data. SDC platinum is likely to miss smaller acquisitions, so we also did an extensive search of public sources (such as Lexis-Nexis,EDGAR and general web searches) to generate a list of all acquisitions for the top 500 patenting corporations in our sample. As this is an iterative process, the resolution of M\&A issues was not completed until the final stages of all our patent and firm matching (i.e. this last step would have been taken after the completion of A.2.1 below). For acquisitions that do not appear in SDC we classify its patents as follows: if the firm is active in 2008 (thus, it is matched to one of the firms in our firm universe) then we classify it as an affiliate of the acquiring corporation. However, in case there is no match between this firm and our firm universe, we classify all of its patents to the acquiring firm headquarters.

Overall, we matched 50,931 patents to SDC and Zephyr. An underlying assumption of this matching is that an affiliate exists in 2008. If the affiliate was historically dissolved it will not appear in our firm universe, hence, its patents will not be included in our sample. In order to overcome this problem, we take two steps. First, for the largest 500 patenting corporations in our sample we manually collect data, from public sources, on their historical acquisitions. This list allows us to identify those firms that were acquired and fully dissolved. Second, we generate a list of the top 1,000 American assignees (as indicated by the address of the assignee) that were not matched to our data. The remaining unmatched firms have less than 40 patents over their lifetime, so it is reasonable to assume that they are not patent-intensive firms. For each unmatched firm remaining in our sample, we manually investigate whether it was acquired by any of our sample parent corporations, or by any firms that themselves were acquired by our parent corporations. These two steps lead us to identify 53,761 patents, which we proceed to classify as centrally assigned. In total, we identify 104,692 as being acquired through a merger or an acquisition. Of these patents, 55,702 (53\%) are assigned to affiliates, and the remaining patents are assigned to headquarters.

For each acquired firm we determine whether it remained operational post-acquisition. We take several steps in determining whether a firm is independent. First, we check whether the firm appears in Amadeus or Icarus as an independent company. Second, we manually check each company listed in the first step whether it continues to operate independently from the parent company. We check their corporate websites to confirm that their legal disclaimers and investor relations information references a parent company. Dissolved acquisitions are much more problematic. Because we match patents to firms based on the 2008 ownership structure, we lose historical acquisitions that were fully integrated in the parent company and ceased to exist as separate legal entities. Though we do capture post-acquisition patents as those are likely to be assigned to headquarters, we may nonetheless over measure decentralization (because all historical patents that we do not match are centralized). To mitigate this problem we performed an exhaustive manual search to identify a significant majority of these absorbed firms and match them to their patents. Appendix A.1.3 for a description of this process. 


\section{A.2 Matching patent data}

We standardize a name cleaning algorithm that is run both on the UO dataset and the 2007 NBER Patent and Citations Dataset in order to match observations by company name. We utilize the assignee codes contained in NBPATS only as quality checks, or for guidance in manual searches, however we concentrate on matches using the affiliate company names and our ultimate owner company names from UO. The algorithm utilizes both automated rules and manual inputs to reduce most firm names to a one or two word string variable. Extensive testing was performed to yield the highest rates of matching, while minimizing multiplicity errors (which occur when two distinct names are rendered equal by deleting distinguishing words). Like previous work in name matching, we capitalize all letters, and remove extraneous characters and strings such as "\&," "THE," "ASSOCIATES," etc. We compile a list of 175 most common such "junk" words (i.e. non-essential for uniquely identifying companies). Our list is more targeted to American firms (our focus) than those lists developed by the NBER Patent Data Project. Furthermore, one refinement over previous such name matching projects is our use of a process whereby junk words are truncated in a right-to-left fashion. This increases the match yield significantly, as we are able to remove, for example, the word "INTERNATIONAL" from "PIONEER HIBRED INTERNATIONAL, INC," (because it occurs on the right side) while allowing it to remain in "INTERNATIONAL BUSINESS MACHINES CORPORATION." To illustrate, the truncation would proceed as follows:

1. Pioneer Hi-Bred International, Inc.

2. PIONEER HI-BRED INTERNATIONAL, INC. (capitalize)

3. PIONEER HI BRED INTERNATIONAL INC (remove punctuation)

4. PIONEER HI BRED INTERNATIONAL (remove last word if "junk")

5. PIONEER HI BRED (remove last word if "junk." Stop)

Here, the algorithm stops when it reaches a "non-junk" word. For "INTERNATIONAL BUSINESS MACHINES CORPORATION," it would have stopped after truncating the word "CORPORATION."

We can further see the power of this "right-to-left" approach by looking at the way that the sub string "HI" above is treated under a different set of conditions. Consider the name "VERIZON INC/HI" (it is common in Compustat to include state identifiers):

1. Verizon Inc./HI

2. VERIZON INC./HI (capitalize)

3. VERIZON INC HI (remove punctuation)

4. VERIZON INC (remove last word if "junk.")

5. VERIZON (remove last word if "junk." Stop)

Here, the sub string "HI" is properly removed, whereas removing it from Pioneer HiBred would have resulted in a corruption of the identifier.

One of the tradeoffs in matching is always between high yield and multiplicity errors. For example, one can see how too aggressive an algorithm can render "American Express," "American Airlines," and "American Standard" into "AMERICAN." Our choice was to err on the side of higher multiplicity, but to rely on manual checks to correct any miscoded companies. By always keeping track of the original, uncleaned names, we added extra steps to check any duplicates (i.e. cases where the same cleaned name corresponded to more than one original name). At this stage, extensive manual effort was expended 
to resolve ambiguities by performing actual checks of patent images and web searches. Ultimately, we match over 846,000 patents to our UO file.

\section{A.2.1 Matching to Compustat}

Having matched patents to firms to ultimate owners, we proceed to match as many ultimate owners as possible to a CUSIP (in order to tap into Compustat accounting information). Because only publicly traded companies are listed by Compustat, this effectively serves as a filter to eliminate government and institutional entities that may have mistakenly made it into our sample by this point. We utilize the standardized matching algorithm used in A.2.1, with some modifications to account for idiosyncratic Compustat "junk words."

\section{A.2.2 Corporate R\&D labs}

An important measure in our analysis is whether a patent is generated at a corporate lab or not. For our purposes, this is a binary outcome, as we are not interested in distance (once a patent is not lab-generated, we do not care how far from headquarters it came from, just as we do not care how far away the lab was from headquarters). We identify the research facilities for the majority of our sample by utilizing the Directory of American Research and Technology, which lists such facilities for all publicly traded companies in America that are considered research-oriented. This gives us the city and zip code information for each firm's R\&D lab facility. Because the directory does not capture every firm in our sample, we compliment this with a manual search that spanned 987 firms. Using publicly available sources such as corporate websties and financial filings, we identify the location for these firm's labs.

Next, we obtain inventor information for all patents from the USPTO database, which is given in string format that provides city or town name and state, for example "Joliet, IL." The first step is to match inventor location to a database of zip codes by utilizing a commercial zip code database obtained from www.zip-codes.com. This entailed significant automated and manual matching due to very different naming conventions utilized by the two data sources. For example, the USPTO city name field contains numerous noise terms such as "Late of" or "Both of," as well as variations of names, such as the following for Sterling Heights, MI and St. Paul, MN:

Sterlin Heights

Sterling

Sterling Hts.

Sterling Hei

Sterling Height

Sterling Heights

Sterling Hgts

Sterling Hgts.

Sterling Hts

Sterling Hts.

St. Pau.

St. Paul 
St. Paul ,all of

St. Paul, all of MN

St. Paul, both of MN

St. Paul, of all

St. Paul.

Once we had zip codes for every inventor for every patent, and every corporate lab for every firm, we proceeded to match them by CBSA code. One limitation faced by many studies that utilize location as a measure concerns the multiple towns, cities, and zip codes are often within the same metropolitan region. Thus, relying solely on Zip code or city name, one would miss that Boston and Cambridge facilities may in fact be within the same R\&D complex. This is even more problematic when we match to inventors, since inventors.addresses are more prone to variation within the area around an R\&D lab (as they live in suburbs, etc.). To counter this, we matched our inventor and lab data data to the US Office of Management and Budget's Core-Based Statistical Areas (CBSA areas), which is accessible at www.census.gov/population/www/metroareas. This database gives us the CBSA code associated with each Zip Codes.

After identifying the CBSA code for each inventor and each lab, we identify every patent in our sample where at least one inventor is located in the same CBSA as a lab (at the firm level). Thus, this patent-level indicator variable lab_match takes on the value of one for patents where we assume that the inventor was affiliated with one of the firm's R\&D labs. Our assumption is that if the patent came from an inventor located in close proximity to a corporate lab, is very likely that she would have been involved with the lab in generating that invention.

\section{A.2.3 Dealing with M\&A}

A central issue in our analysis is the post-merger management of acquired firms. The decentralization variation in our data comes mostly from two sources: the degree of postacquisition integration of affiliates (with a lower bound being those kept independent), and the speed at which patents are generated centrally in relation to existing affiliates. For each acquired firm we determine whether it remained independent post-acquisition, or whether it was dissolved. We take several steps in determining whether a firm is independent. First, we check whether the firm appears in Amadeus or Icarus as an independent company. Second, we manually check each company listed in the first step whether it continues to operate independently from the parent company. We check their corporate websites to confirm that their legal disclaimers and investor relations information references a parent company.

Dissolved acquisitions are much more problematic. Because we match patents to firms based on the 2008 ownership structure, we lose historical acquisitions that were fully integrated in the parent company and ceased to exist as separate legal entities. Though we do capture post-acquisition patents as those are likely to be assigned to headquarters, we may nonetheless over measure decentralization (because all historical patents that we do not match are centralized). To mitigate this problem we take two steps. We match all firms in SDC Platinum where the acquiring firm appears in our sample. We then add to our data all patents that belong to acquired firms that no longer appear in the 2008 data. SDC platinum is likely to miss smaller acquisitions, so we also did an extensive search 
of public sources (such as Lexis-Nexis,EDGAR and general web searches) to generate a list of all acquisitions for the top 500 patenting corporations in our sample. As this is an iterative process, the resolution of M\&A issues was not completed until the final stages of all our patent and firm matching (i.e. this last step would have been taken after the completion of A.2.1 below). For acquisitions that do not appear in SDC we classify its patents as follows: if the firm is active in 2008 (thus, it is matched to one of the firms in our firm universe) then we classify it as an affiliate of the acquiring corporation. However, in case there is no match between this firm and our firm universe, we classify all of its patents to the acquiring firm headquarters.

Overall, we matched 50,931 patents to SDC and Zephyr. An underlying assumption of this matching is that an affiliate exists in 2008. If the affiliate was historically dissolved it will not appear in our firm universe, hence, its patents will not be included in our sample. In order to overcome this problem, we take two steps. First, for the largest 500 patenting corporations in our sample we manually collect data, from public sources, on their historical acquisitions. This list allows us to identify those firms that were acquired and fully dissolved. Second, we generate a list of the top 1,000 American assignees (as indicated by the address of the assignee) that were not matched to our data. The remaining unmatched firms have less than 40 patents over their lifetime, so it is reasonable to assume that they are not patent-intensive firms. For each unmatched firm remaining in our sample, we manually investigate whether it was acquired by any of our sample parent corporations, or by any firms that themselves were acquired by our parent corporations. These two steps lead us to identify 53,761 patents, which we proceed to classify as centrally assigned. In total, we identify 104,692 as being acquired through a merger or an acquisition. Of these patents, 55,702 (53\%) are assigned to affiliates, and the remaining patents are assigned to headquarters.

\section{A.3 Reassignments}

Our measures of assignment structure builds on the assignee name that appears on the patent document when it was granted. Patent assignment can change over time. To test the robustness of our results to changes in assignment, we develop comprehensive data on patent reassignment. Reassignment data are taken directly from the USPTO website (using a specialized "spider" program), and then merged to our final patent sample. We are interested in two reassignment types: (i) assigning a patent that was originally assigned to headquarters to an affiliates, and (ii) reassigning to headquarters a patent that was originally assigned to an affiliate. ${ }^{1213}$ To determine reassignment type we match old and new assignees to our firm name sample. Some patents undergo reassignments over their lifetime for reasons that are not germane to our study. For example, patents are very often reassigned to correct errors in the initial document, or for purposes of collateralization for

\footnotetext{
${ }^{12}$ For example, we find evidence of the first type of reassignment in many patents held by Boston Scientific, which were assigned to affiliates such as Advanced Bionics and Sci Med Life Systems years after Boston Scientific bought them. As well, we see patents going from acquired affiliate to headquarters, for example Matrix Semiconductor assigning 157 of its 421 patents to parent company Sandisk.

${ }^{13} \mathrm{~A}$ third type of reassignment is inter-firm. Because the current paper deals with intra-firm allocation of IP rights, we exclude inter-firm reassignment from our sample.
} 
lenders (which results in multiple reassignments, as when the status of the loan changes). Ultimately, 41,244 patents in our sample are meaningfully reassigned. Close to 90(36,180 patents), supporting our view of assignments as being associated with a long-term effective delegation of authority. Furthermore, although not discussed in detail in the text, our results are robust to adjusting for reassignments. 


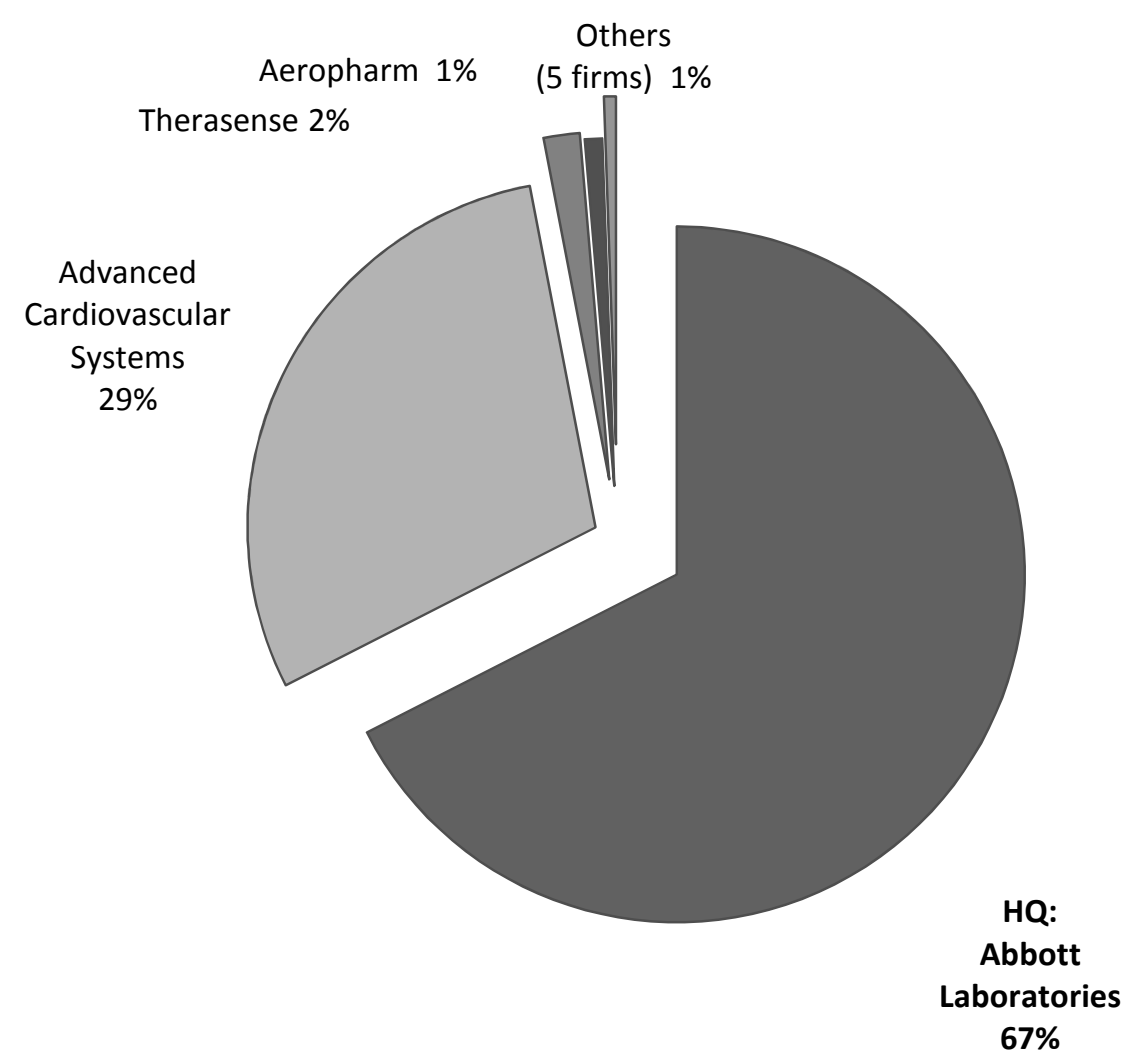

Abbott Laboratories
Depuy Spine 1\%

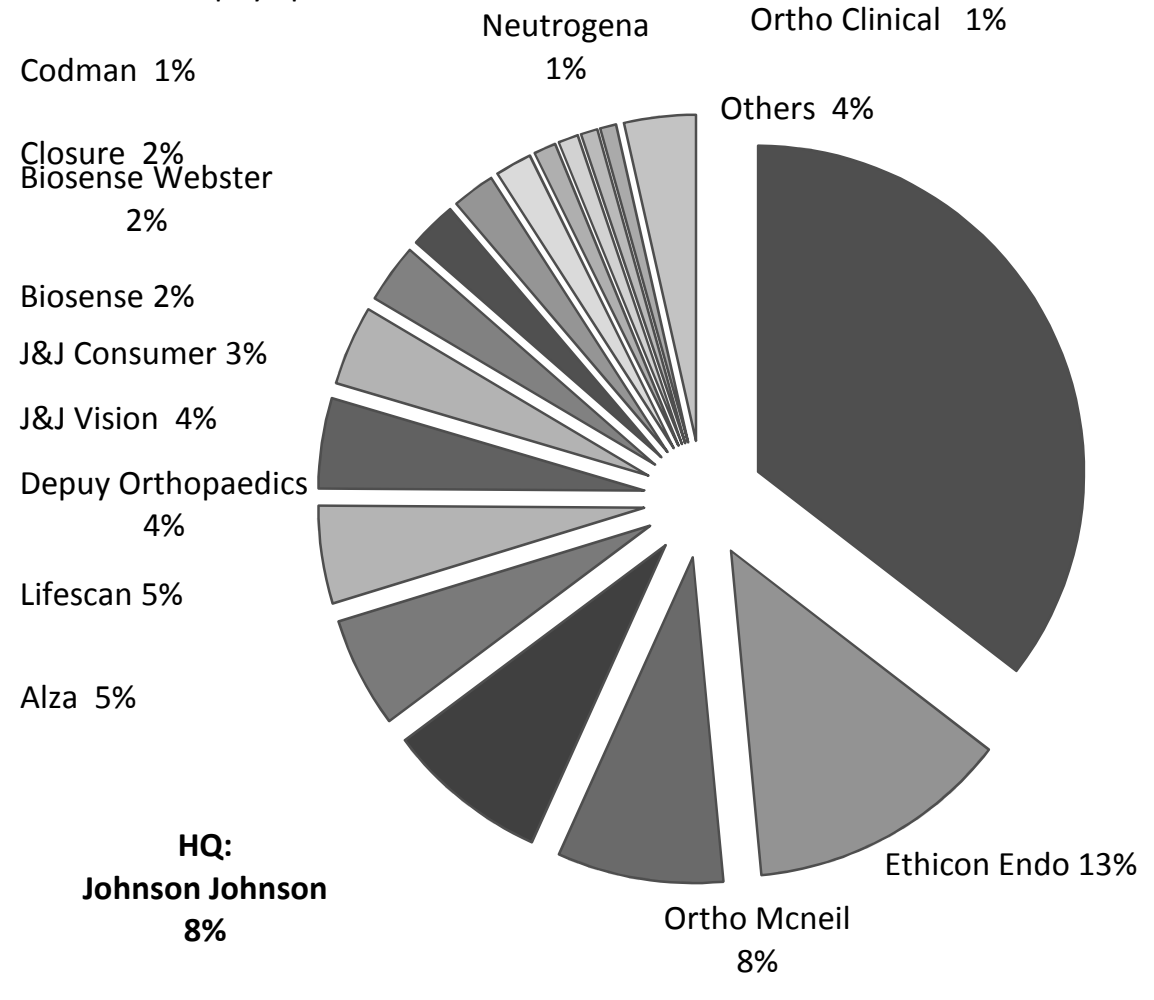

\section{Johnson \& Johnson}

Figure 1: Example of Centralized vs. decentralized patent assignments 
Table 1. Summary Statistics for Main Variables

\begin{tabular}{|c|c|c|c|c|c|c|}
\hline \multirow[b]{2}{*}{ Variable } & \multirow[b]{2}{*}{ \# Obs. } & \multirow[b]{2}{*}{ Mean } & \multirow[b]{2}{*}{ Std. Dev. } & \multicolumn{3}{|c|}{ Distribution } \\
\hline & & & & $10^{\text {th }}$ & $50^{\text {th }}$ & $90^{\text {th }}$ \\
\hline \multicolumn{7}{|c|}{ Panel A: Firms (Firm-Year) } \\
\hline Share asssigned patents ${ }_{t-1}$ & 16,104 & 0.33 & 0.42 & 0 & 0.03 & 1 \\
\hline Share lab patents ${ }_{t-1}$ & 16,104 & 0.27 & 0.67 & 0 & 0 & 1 \\
\hline Market Value (\$mm) & 16,104 & 1,430 & 7,104 & 4 & 126 & 2,936 \\
\hline Tobin's $Q$ & 16,104 & 1.15 & 2.13 & 0.14 & 0.58 & 2.34 \\
\hline Sales Growth & 16,031 & 0.105 & 0.358 & -0.012 & 0.084 & 0.360 \\
\hline Sales $_{t-1}(\$ \mathrm{~mm})$ & 14,562 & 3,616 & 11,964 & 34 & 596 & 8,227 \\
\hline Assets $_{t-1}(\$ \mathrm{~mm})$ & 16,104 & 2,091 & 7,272 & 11 & 197 & 4,725 \\
\hline$R \& D$ Expenditures $(\$ \mathrm{~mm})$ & 16,104 & 109 & 472 & 0 & 5.3 & 183 \\
\hline$R \& D$ Stock $_{t-1}(\$ \mathrm{~mm})$ & 16,104 & 452 & 1,819 & 0 & 22 & 814 \\
\hline Patents Stock $_{t-1}$ & 16,104 & 153 & 611 & 0.6 & 14 & 266 \\
\hline Patents flow, count & 16,104 & 25 & 99 & 0 & 2 & 48 \\
\hline Patents flow, weighed by cites & 16,104 & 20 & 88 & 0 & 1 & 31 \\
\hline \multicolumn{7}{|c|}{ Panel B: Patents } \\
\hline Dummy for Decentralized & 595,710 & 0.18 & 0.39 & 0 & 0 & 1 \\
\hline Dummy for lab generated & 595,710 & 0.34 & 0.47 & 0 & 0 & 1 \\
\hline Generality & 404,632 & 0.57 & 0.32 & 0 & 0.66 & 1 \\
\hline Originality & 433,449 & 0.27 & 0.28 & 0 & 0.22 & 0.67 \\
\hline Citations per Patent & 595,710 & 8.90 & 15.90 & 0 & 4 & 22 \\
\hline Citations per Patent $(>0)$ & 430,237 & 11.30 & 17.10 & 1 & 6 & 26 \\
\hline Citations to Non-Patent Lit. & 595,710 & 0.78 & 3.89 & 0 & 0 & 2 \\
\hline Citations to Non-Patent Lit. $(>0)$ & 106,578 & 4.30 & 8.30 & 1 & 2 & 9 \\
\hline
\end{tabular}

Notes: This table provides summary statistics for key variables used in the econometric analysis. Market Value includes common stock, preferred stock and debt, net of current assets. Tobin's $Q$ is the ratio between Market Value and Assets. $R \& D$ Stock is computed using the perpetual inventory method with a depreciation rate of $15 \%$. Patents Stock is citations-weighted and is computed using the perpetual inventory method with a depreciation rate of $15 \%$. Share assigned patents divides a firm's total number of affiliate-assigned patents by its total number of patents. Generality is the HHI measure of concentration of the citations a patent receives across three-digit U.S. class. Originality is the HHI measure of concentration of the citations a patent makes across three-digit U.S. class. Citations to Non-Patent Lit. is the number of citations a patent makes to non-patent literature. 
Table 2. Patent Characteristics by Assignement and R\&D Location

\begin{tabular}{|c|c|c|c|c|c|c|}
\hline \multirow[b]{2}{*}{ Variable } & \multicolumn{2}{|c|}{ All } & \multicolumn{2}{|c|}{ Affiliate R\&D } & \multicolumn{2}{|c|}{ Central R\&D } \\
\hline & Obs. & $\begin{array}{c}\text { Affiliate minus } \\
\text { HQ assigned }\end{array}$ & Obs. & $\begin{array}{c}\text { Affiliate minus } \\
\text { HQ assigned }\end{array}$ & Obs. & $\begin{array}{c}\text { Affiliate minus } \\
\text { HQ assigned }\end{array}$ \\
\hline Number of citations & 595,710 & $-0.414 * *$ & 394,389 & $-0.491 * *$ & 201,321 & $-0.225^{* *}$ \\
\hline Number of citations $(>0)$ & 430,237 & $-0.557 * *$ & 281,387 & $-0.869 * *$ & 148,850 & 0.101 \\
\hline Citations to Non-Patent Lit. & 595,710 & $-0.226 * *$ & 394,389 & $-0.283 * *$ & 201,321 & -0.132 \\
\hline Citations to Non-Patent Lit. $(>0)$ & 106,578 & $-0.366^{* *}$ & 73,171 & $-0.464 * *$ & 33,407 & -0.198 \\
\hline Generality & 404,632 & $-0.018 * *$ & 263,085 & $-0.019 * *$ & 141,547 & $-0.015^{* *}$ \\
\hline
\end{tabular}

Notes: This table reports mean comparison tests for affiliate assigned and HQ assigned patents by the location of R\&D. Share assigned patents divides a firm's total number of affiliate-assigned patents by its total number of patents. $* *$ denotes that the difference in means is significant at the 1 percent level. 
Table 3. Affiliate patent assignment

Dependent variable: Dummy for affiliate assignment. Probit Estimation (marginal effects)

\begin{tabular}{|c|c|c|c|c|c|c|c|}
\hline & $(1)$ & $(2)$ & $(3)$ & $(4)$ & $(5)$ & (6) & (7) \\
\hline & & $\begin{array}{c}\text { At least one } \\
\text { cite }\end{array}$ & & $\begin{array}{c}\text { MSA } \\
\text { controls }\end{array}$ & $\begin{array}{c}\text { Excluding } \\
\text { Pre-M\&A } \\
\text { Patents }\end{array}$ & $\begin{array}{c}\text { From central } \\
\text { lab }\end{array}$ & $\begin{array}{l}\text { Not from } \\
\text { central lab }\end{array}$ \\
\hline $\ln (1+$ Citations Received $)$ & $\begin{array}{c}-0.016 * * \\
(0.001)\end{array}$ & $\begin{array}{c}-0.018 * * \\
(0.001)\end{array}$ & $\begin{array}{c}-0.017 * * \\
(0.001)\end{array}$ & $\begin{array}{c}-0.013 * * \\
(0.001)\end{array}$ & $\begin{array}{c}-0.013 * * \\
(0.001)\end{array}$ & $\begin{array}{c}-0.003 * * \\
(0.001)\end{array}$ & $\begin{array}{c}-0.025 * * \\
(0.0009)\end{array}$ \\
\hline $\ln (1+$ Citations to Non-Patent Lit. $)$ & $\begin{array}{c}-0.016 * * \\
(0.001)\end{array}$ & $\begin{array}{c}-0.017 * * \\
(0.001)\end{array}$ & $\begin{array}{c}-0.016 * * \\
(0.001)\end{array}$ & $\begin{array}{c}-0.017 * * \\
(0.001)\end{array}$ & $\begin{array}{c}-0.008 * * \\
(0.001)\end{array}$ & $\begin{array}{c}-0.007 * * \\
(0.002)\end{array}$ & $\begin{array}{c}-0.020 * * \\
(0.001)\end{array}$ \\
\hline Patent Generality & $\begin{array}{c}-0.018 * * \\
(0.002)\end{array}$ & $\begin{array}{c}-0.019 * * \\
(0.002)\end{array}$ & $\begin{array}{c}-0.016^{* *} \\
(0.002)\end{array}$ & $\begin{array}{c}-0.018 * * \\
(0.002)\end{array}$ & $\begin{array}{c}-0.018 * * \\
(0.002)\end{array}$ & $\begin{array}{c}-0.011 * * \\
(0.003)\end{array}$ & $\begin{array}{c}-0.201 * * \\
(0.002)\end{array}$ \\
\hline Patent Originality & $\begin{array}{c}-0.010 * * \\
(0.002)\end{array}$ & $\begin{array}{c}-0.011 * * \\
(0.002)\end{array}$ & $\begin{array}{c}-0.010 * * \\
(0.002)\end{array}$ & $\begin{array}{l}-0.003 \\
(0.002)\end{array}$ & $\begin{array}{l}-0.003 \\
(0.002)\end{array}$ & $\begin{array}{c}-0.009 * * \\
(0.002)\end{array}$ & $\begin{array}{c}-0.014 * * \\
(0.002)\end{array}$ \\
\hline Firm Diversity (HHI) & & & $\begin{array}{c}-0.077 * * \\
(0.005)\end{array}$ & & & & \\
\hline \multicolumn{8}{|l|}{ Technology areas dummies: } \\
\hline Biotechnology & $\begin{array}{c}0.017 * * \\
(0.006)\end{array}$ & $\begin{array}{l}0.012 \\
(0.007)\end{array}$ & $\begin{array}{l}0.002 \\
(0.006)\end{array}$ & $\begin{array}{l}-0.003 \\
(0.006)\end{array}$ & $\begin{array}{l}-0.003 \\
(0.006)\end{array}$ & $\begin{array}{c}0.016 * * \\
(0.006)\end{array}$ & $\begin{array}{c}0.017 * * \\
(0.006)\end{array}$ \\
\hline Chemicals & $\begin{array}{c}-0.019 * * \\
(0.003)\end{array}$ & $\begin{array}{c}-0.018 * * \\
(0.004)\end{array}$ & $\begin{array}{c}-0.014 * * \\
(0.003)\end{array}$ & $\begin{array}{l}-0.005 \\
(0.003)\end{array}$ & $\begin{array}{l}-0.006 \\
(0.003)\end{array}$ & $\begin{array}{c}-0.019 * * \\
(0.003)\end{array}$ & $\begin{array}{c}-0.018 * * \\
(0.003)\end{array}$ \\
\hline Telecommunications & $\begin{array}{c}-0.105 * * \\
(0.004)\end{array}$ & $\begin{array}{c}-0.096 * * \\
(0.005)\end{array}$ & $\begin{array}{c}-0.080 * * \\
(0.004)\end{array}$ & $\begin{array}{c}-0.071 * * \\
(0.004)\end{array}$ & $\begin{array}{c}-0.072 * * \\
(0.004)\end{array}$ & $\begin{array}{c}-0.101 * * \\
(0.004)\end{array}$ & $\begin{array}{c}-0.100 * * \\
(0.004)\end{array}$ \\
\hline Electronics & $\begin{array}{c}-0.109 * * \\
(0.004)\end{array}$ & $\begin{array}{c}-0.102 * * \\
(0.004)\end{array}$ & $\begin{array}{c}-0.095 * * \\
(0.004)\end{array}$ & $\begin{array}{c}-0.079 * * \\
(0.003)\end{array}$ & $\begin{array}{c}-0.079 * * \\
(0.003)\end{array}$ & $\begin{array}{c}-0.081 * * \\
(0.004)\end{array}$ & $\begin{array}{c}-0.092 * * \\
(0.004)\end{array}$ \\
\hline Semiconductors & $\begin{array}{c}-0.269 * * \\
(0.005)\end{array}$ & $\begin{array}{c}-0.289 * * \\
(0.006)\end{array}$ & $\begin{array}{c}-0.240 * * \\
(0.005)\end{array}$ & $\begin{array}{c}-0.199 * * \\
(0.005)\end{array}$ & $\begin{array}{c}-0.198 * * \\
(0.005)\end{array}$ & $\begin{array}{c}-0.251 * * \\
(0.005)\end{array}$ & $\begin{array}{c}-0.247 * * \\
(0.005)\end{array}$ \\
\hline Information Technology & $\begin{array}{c}-0.190 * * \\
(0.004)\end{array}$ & $\begin{array}{c}-0.185 * * \\
(0.004)\end{array}$ & $\begin{array}{c}-0.157 * * \\
(0.004)\end{array}$ & $\begin{array}{c}-0.140 * * \\
(0.004)\end{array}$ & $\begin{array}{c}-0.141 * * \\
(0.004)\end{array}$ & $\begin{array}{c}-0.154 * * \\
(0.004)\end{array}$ & $\begin{array}{c}-0.162 * * \\
(0.004)\end{array}$ \\
\hline Engineering & $\begin{array}{c}-0.031 * * \\
(0.004)\end{array}$ & $\begin{array}{c}-0.023 * * \\
(0.004)\end{array}$ & $\begin{array}{c}-0.041 * * \\
(0.004)\end{array}$ & $\begin{array}{c}-0.016 * * \\
(0.004)\end{array}$ & $\begin{array}{c}-0.017 * * \\
(0.004)\end{array}$ & $\begin{array}{c}-0.030 * * \\
(0.004)\end{array}$ & $\begin{array}{c}-0.028 * * \\
(0.004)\end{array}$ \\
\hline$\%$ Affiliated & 18.4 & 18.9 & 18.4 & 18.4 & 12.0 & 14.5 & 20.4 \\
\hline $\mathrm{R}^{2}$ & 0.0379 & 0.037 & 0.043 & 0.111 & 0.052 & 0.060 & 0.052 \\
\hline Observations & 594,903 & 467,246 & 594,903 & 594,903 & 551,237 & 200,514 & 394,389 \\
\hline
\end{tabular}

Notes: This table reports the estimation results of a Probit model that examines the determinants of decentralization. The base technology area is Pharmaceuticals. We assign specific codes, and include respective dummy variables for patents that receive (make) less than two citations. For these patents Generality (Originality) is not defined. All columns include an unreported Other technology category. Firm Diversity (column 3) is computed as the HHI measure of concentration of firm's patents across two-digit IPC. Standard errors (in brackets) are robust to arbitrary heteroskedasticity and allow for serial correlation. **, * denote significance levels of 1 and 5 percent, respectively. 
Table 4. R\&D Equation

\begin{tabular}{|c|c|c|c|c|c|c|c|c|c|}
\hline & (1) & (2) & (3) & (4) & (5) & (6) & $(7)$ & $(8)$ & (9) \\
\hline \multirow[t]{2}{*}{ Dependent variable: } & \multicolumn{6}{|c|}{$\ln (R \& D)$} & \multicolumn{3}{|c|}{$\ln (R \& D /$ Sales $)$} \\
\hline & & & & & & $\begin{array}{c}\text { MSA } \\
\text { controls }\end{array}$ & & & $\begin{array}{c}\text { MSA } \\
\text { controls }\end{array}$ \\
\hline Share assigned $\mathrm{t}_{-1}$ & $\begin{array}{c}-0.303 * * \\
(0.063)\end{array}$ & $\begin{array}{c}-0.292 * * \\
(0.062)\end{array}$ & $\begin{array}{c}-0.298 * * \\
(0.062)\end{array}$ & & $\begin{array}{c}-0.337 * * \\
(0.064)\end{array}$ & $\begin{array}{c}-0.220 * * \\
(0.056)\end{array}$ & $\begin{array}{c}-0.323 * * \\
(0.061)\end{array}$ & $\begin{array}{c}-0.317 * * \\
(0.061)\end{array}$ & $\begin{array}{c}-0.241 * * \\
(0.056)\end{array}$ \\
\hline Dummy for a lab & & $\begin{array}{c}0.167 * * \\
(0.069)\end{array}$ & $\begin{array}{c}0.204 * * \\
(0.074)\end{array}$ & $\begin{array}{c}0.210^{* *} \\
(0.075)\end{array}$ & $\begin{array}{c}0.205^{* *} \\
(0.074)\end{array}$ & $\begin{array}{l}0.130 \\
(0.073)\end{array}$ & & $\begin{array}{c}0.183 * * \\
(0.071)\end{array}$ & $\begin{array}{l}0.109 \\
(0.070)\end{array}$ \\
\hline Share of lab patents & & & $\begin{array}{l}-0.056 \\
(0.034)\end{array}$ & $\begin{array}{l}-0.045 \\
(0.035)\end{array}$ & $\begin{array}{l}-0.053 \\
(0.033)\end{array}$ & $\begin{array}{c}-0.044 \\
(0.031)\end{array}$ & & $\begin{array}{l}-0.046 \\
(0.032)\end{array}$ & $\begin{array}{l}-0.041 \\
(0.030)\end{array}$ \\
\hline Share $M \& A$ patents $_{\mathrm{t}-1}$ & & & & & $\begin{array}{l}0.102 \\
(0.068)\end{array}$ & & & & \\
\hline $\ln (1+$ No. Affiliates $)$ & $\begin{array}{l}0.025 \\
(0.021)\end{array}$ & $\begin{array}{l}0.017 \\
(0.021)\end{array}$ & $\begin{array}{l}0.016 \\
(0.021)\end{array}$ & $\begin{array}{l}0.011 \\
(0.021)\end{array}$ & $\begin{array}{l}0.013 \\
(0.021)\end{array}$ & $\begin{array}{l}0.014 \\
(0.021)\end{array}$ & $\begin{array}{l}0.004 \\
(0.020)\end{array}$ & $\begin{array}{l}-0.004 \\
(0.020)\end{array}$ & $\begin{array}{l}-0.010 \\
(0.020)\end{array}$ \\
\hline $\ln (\text { Sales })_{\mathrm{t}-1}$ & $\begin{array}{c}0.771 * * \\
(0.022)\end{array}$ & $\begin{array}{c}0.760 * * \\
(0.023)\end{array}$ & $\begin{array}{c}0.760 * * \\
(0.023)\end{array}$ & $\begin{array}{c}0.762 * * \\
(0.023)\end{array}$ & $\begin{array}{c}0.759 * * \\
(0.023)\end{array}$ & $\begin{array}{c}0.747 * * \\
(0.022)\end{array}$ & $\begin{array}{c}-0.186 * * \\
(0.021)\end{array}$ & $\begin{array}{c}-0.196 * * \\
(0.022)\end{array}$ & $\begin{array}{c}-0.203 * * \\
(0.021)\end{array}$ \\
\hline Four-digit SIC dummies & Yes & Yes & Yes & Yes & Yes & Yes & Yes & Yes & Yes \\
\hline Year dummies & Yes & Yes & Yes & Yes & Yes & Yes & Yes & Yes & Yes \\
\hline $\begin{array}{l}\text { Shares of patents by MSA } \\
\text { (197 region controls) }\end{array}$ & No & No & No & No & Yes & Yes & No & No & No \\
\hline $\mathrm{R}^{2}$ & 0.823 & 0.824 & 0.825 & 0.823 & 0.825 & 0.858 & 0.661 & 0.663 & 0.726 \\
\hline Observations & 11,168 & 11,168 & 11,168 & 11,168 & 11,168 & 11,168 & 11,165 & 11,165 & 11,165 \\
\hline
\end{tabular}

Notes: This table reports the estimation results of the relation between R\&D expenditure and decentralization. Share assigned divides a firm's total number of affiliate-assigned patents by its total number of patents. Dummy for lab receives the value of one for corporations that have at least one R\&D lab, and zero for corporations that have no recorded R\&D labs. Shares of patents by MSA is a complete set of share variables of the firm patents distribution across 197 MSA regions. Standard errors (in brackets) are robust to arbitrary heteroskedasticity and allow for serial correlation through clustering by firms. **, * denote significance levels of 1 and 5 percent, respectively. 
Table 5. Patents Equation

\begin{tabular}{|c|c|c|c|c|c|c|c|c|c|}
\hline & $(1)$ & $(2)$ & (3) & (4) & $(5)$ & (6) & (7) & (8) & (9) \\
\hline \multirow[t]{2}{*}{ Dependent variable: } & \multicolumn{5}{|c|}{$\ln (1+$ Patents $)$} & \multicolumn{4}{|c|}{$\ln [(1+$ Patents $) / R \& D$ stock $]$} \\
\hline & & & & $\begin{array}{c}\text { MSA } \\
\text { controls }\end{array}$ & $\begin{array}{l}\text { Weighed } \\
\text { by cites }\end{array}$ & & & & $\begin{array}{c}\text { MSA } \\
\text { controls }\end{array}$ \\
\hline Share assigned $\mathrm{t}_{\mathrm{t}-1}$ & $\begin{array}{c}-0.164 * * \\
(0.056)\end{array}$ & $\begin{array}{c}-0.154^{* *} \\
(0.055)\end{array}$ & $\begin{array}{c}-0.108^{*} \\
(0.057)\end{array}$ & $\begin{array}{c}-0.180 * * \\
(0.057)\end{array}$ & $\begin{array}{c}-0.154 * * \\
(0.055)\end{array}$ & $\begin{array}{c}-0.187 * * \\
(0.057)\end{array}$ & $\begin{array}{c}-0.176^{* *} \\
(0.056)\end{array}$ & $\begin{array}{c}-0.122^{*} \\
(0.058)\end{array}$ & $\begin{array}{c}-0.203 * * \\
(0.059)\end{array}$ \\
\hline Dummy for a lab & & $\begin{array}{c}0.198 * * \\
(0.068)\end{array}$ & $\begin{array}{c}0.196 * * \\
(0.068)\end{array}$ & $\begin{array}{c}0.136^{*} \\
(0.068)\end{array}$ & $\begin{array}{c}0.198 * * \\
(0.068)\end{array}$ & & $\begin{array}{c}0.209 * * \\
(0.069)\end{array}$ & $\begin{array}{c}0.206^{* *} \\
(0.069)\end{array}$ & $\begin{array}{l}0.147^{*} \\
(0.068)\end{array}$ \\
\hline Share of lab patents & & $\begin{array}{l}0.030 \\
(0.040)\end{array}$ & $\begin{array}{l}0.025 \\
(0.040)\end{array}$ & $\begin{array}{l}0.050 \\
(0.036)\end{array}$ & $\begin{array}{l}0.030 \\
(0.040)\end{array}$ & & $\begin{array}{l}0.040 \\
(0.039)\end{array}$ & $\begin{array}{l}0.035 \\
(0.039)\end{array}$ & $\begin{array}{l}0.055 \\
(0.035)\end{array}$ \\
\hline Share $M \& A$ patents $_{\mathrm{t}-1}$ & & & $\begin{array}{l}-0.126 \\
(0.069)\end{array}$ & & & & & $\begin{array}{c}-0.146^{*} \\
(0.069)\end{array}$ & \\
\hline $\ln (1+$ No. Affiliates $)$ & $\begin{array}{c}0.069 * * \\
(0.024)\end{array}$ & $\begin{array}{c}0.061 * * \\
(0.023)\end{array}$ & $\begin{array}{c}0.066^{* *} \\
(0.023)\end{array}$ & $\begin{array}{c}0.057 * * \\
(0.024)\end{array}$ & $\begin{array}{c}0.061 * * \\
(0.023)\end{array}$ & $\begin{array}{c}0.067 * * \\
(0.024)\end{array}$ & $\begin{array}{c}0.059 * * \\
(0.024)\end{array}$ & $\begin{array}{c}0.065^{* *} \\
(0.023)\end{array}$ & $\begin{array}{c}0.053^{*} \\
(0.025)\end{array}$ \\
\hline $\ln (\text { Sales })_{\mathrm{t}-1}$ & $\begin{array}{c}0.145^{* *} \\
(0.022)\end{array}$ & $\begin{array}{c}0.135 * * \\
(0.021)\end{array}$ & $\begin{array}{c}0.137 * * \\
(0.021)\end{array}$ & $\begin{array}{c}0.136^{* *} \\
(0.019)\end{array}$ & $\begin{array}{c}0.135^{* *} \\
(0.021)\end{array}$ & $\begin{array}{c}0.127 * * \\
(0.025)\end{array}$ & $\begin{array}{c}0.116^{* *} \\
(0.024)\end{array}$ & $\begin{array}{c}0.118^{* *} \\
(0.024)\end{array}$ & $\begin{array}{c}0.108 * * \\
(0.021)\end{array}$ \\
\hline $\ln (R \& D \text { Stock })_{\mathrm{t}-1}$ & $\begin{array}{c}0.360 * * \\
(0.026)\end{array}$ & $\begin{array}{c}0.353 * * \\
(0.026)\end{array}$ & $\begin{array}{c}0.352 * * \\
(0.026)\end{array}$ & $\begin{array}{c}0.329 * * \\
(0.023)\end{array}$ & $\begin{array}{c}0.353 * * \\
(0.026)\end{array}$ & $\begin{array}{c}-0.585^{* *} \\
(0.031)\end{array}$ & $\begin{array}{c}-0.592 * * \\
(0.030)\end{array}$ & $\begin{array}{c}-0.593 * * \\
(0.030)\end{array}$ & $\begin{array}{c}-0.601 * * \\
(0.026)\end{array}$ \\
\hline $\begin{array}{l}\text { Four-digit SIC } \\
\text { dummies }\end{array}$ & Yes & Yes & Yes & Yes & Yes & Yes & Yes & Yes & Yes \\
\hline $\begin{array}{l}\text { Year dummies } \\
\text { Shares of patents by }\end{array}$ & Yes & Yes & Yes & Yes & Yes & Yes & Yes & Yes & Yes \\
\hline $\begin{array}{l}\text { MSA (197 region } \\
\text { controls) }\end{array}$ & No & No & Yes & Yes & Yes & No & No & Yes & Yes \\
\hline $\mathrm{R}^{2}$ & 0.652 & 0.655 & 0.656 & 0.697 & 0.655 & 0.819 & 0.821 & 0.821 & 0.841 \\
\hline Observations & 10,796 & 10,796 & 10,796 & 10,796 & 10,796 & 10,796 & 10,796 & 10,796 & 10,796 \\
\hline
\end{tabular}

Notes: This table reports the estimation results of the relation between patenting activity and decentralization. Share assigned divides a firm's total number of affiliate-assigned patents by its total number of patents. Dummy for lab receives the value of one for corporations that have at least one R\&D lab, and zero for corporations that have no recorded R\&D labs. Shares of patents by MSA is a complete set of share variables of the firm patents distribution across 197 MSA regions. In columns 4 and 8 the number of patents are weighed by the number of citations they receive. The weight for patent is the ratio between the number of citations it received and the average number of citations received by all patents that are granted in the same year as the focal patent. Standard errors (in brackets) are robust to arbitrary heteroskedasticity and allow for serial correlation through clustering by firms. **, * denote significance levels of 1 and 5 percent, respectively. 
Table 6. Sales Growth Equation

\begin{tabular}{|c|c|c|c|c|c|c|}
\hline \multicolumn{7}{|c|}{ Dependent variable: $\Delta \ln (\text { Sales })_{\mathrm{t}-1}$} \\
\hline & (1) & (2) & (3) & (4) & (5) & (6) \\
\hline & & & & $\begin{array}{c}\text { MSA } \\
\text { controls }\end{array}$ & $\begin{array}{c}\text { Have a } \\
\text { central lab }\end{array}$ & $\begin{array}{c}\text { No central } \\
\text { lab }\end{array}$ \\
\hline Share assigned $_{\mathrm{t}-1}$ & $\begin{array}{c}0.037 * * \\
(0.010)\end{array}$ & $\begin{array}{c}0.037 * * \\
(0.010)\end{array}$ & $\begin{array}{c}0.022 * \\
(0.010)\end{array}$ & $\begin{array}{c}0.039 * * \\
(0.010)\end{array}$ & $\begin{array}{c}0.043 * * \\
(0.014)\end{array}$ & $\begin{array}{l}0.024 \\
(0.015)\end{array}$ \\
\hline Dummy for a lab & & $\begin{array}{c}0.019^{*} \\
(0.010)\end{array}$ & $\begin{array}{c}0.020^{*} \\
(0.010)\end{array}$ & $\begin{array}{l}0.013 \\
(0.011)\end{array}$ & & \\
\hline Share lab patents $_{\mathrm{t}-1}$ & & $\begin{array}{c}-0.013 * * \\
(0.005)\end{array}$ & $\begin{array}{c}-0.011 * * \\
(0.005)\end{array}$ & $\begin{array}{l}-0.006 \\
(0.005)\end{array}$ & & \\
\hline Share $M \& A$ patents $_{\mathrm{t}-1}$ & & & $\begin{array}{c}0.044 * * \\
(0.011)\end{array}$ & & & \\
\hline $\ln (R \& D \text { Stock })_{\mathrm{t}-1}$ & $\begin{array}{l}0.004 \\
(0.004)\end{array}$ & $\begin{array}{l}0.004 \\
(0.004)\end{array}$ & $\begin{array}{l}0.004 \\
(0.004)\end{array}$ & $\begin{array}{l}0.004 \\
(0.004)\end{array}$ & $\begin{array}{l}-0.002 \\
(0.007)\end{array}$ & $\begin{array}{l}0.011 \\
(0.006)\end{array}$ \\
\hline $\ln (1+$ No. Affiliates $)$ & $\begin{array}{c}0.018^{* *} \\
(0.003)\end{array}$ & $\begin{array}{c}0.018 * * \\
(0.003)\end{array}$ & $\begin{array}{c}0.016^{* *} \\
(0.003)\end{array}$ & $\begin{array}{c}0.020 * * \\
(0.004)\end{array}$ & $\begin{array}{c}0.015^{* *} \\
(0.005)\end{array}$ & $\begin{array}{c}0.028^{* *} \\
(0.005)\end{array}$ \\
\hline $\ln (1+\text { Patents stock })_{\mathrm{t}-1}$ & $\begin{array}{l}0.006 \\
(0.004)\end{array}$ & $\begin{array}{l}0.005 \\
(0.004)\end{array}$ & $\begin{array}{l}0.005 \\
(0.004)\end{array}$ & $\begin{array}{l}0.005 \\
(0.004)\end{array}$ & $\begin{array}{c}0.015 * * \\
(0.005)\end{array}$ & $\begin{array}{l}-0.003 \\
(0.006)\end{array}$ \\
\hline $\ln (\text { Sales })_{\mathrm{t}-1}$ & $\begin{array}{c}-0.105 * * \\
(0.021)\end{array}$ & $\begin{array}{c}-0.105 * * \\
(0.021)\end{array}$ & $\begin{array}{c}-0.107 * * \\
(0.021)\end{array}$ & $\begin{array}{c}-0.114 * * \\
(0.022)\end{array}$ & $\begin{array}{c}-0.107 * \\
(0.048)\end{array}$ & $\begin{array}{c}-0.124 * * \\
(0.024)\end{array}$ \\
\hline $\ln (\text { Assets })_{\mathrm{t}-1}$ & $\begin{array}{c}0.063 * * \\
(0.018)\end{array}$ & $\begin{array}{c}0.064 * * \\
(0.018)\end{array}$ & $\begin{array}{c}0.065^{* *} \\
(0.018)\end{array}$ & $\begin{array}{c}0.069 * * \\
(0.019)\end{array}$ & $\begin{array}{l}0.060 \\
(0.042)\end{array}$ & $\begin{array}{c}0.077 * * \\
(0.022)\end{array}$ \\
\hline Four-digit SIC dummies & Yes & Yes & Yes & Yes & Yes & Yes \\
\hline Year dummies & Yes & Yes & Yes & Yes & Yes & Yes \\
\hline $\begin{array}{l}\text { Shares of patents by MSA ( } 197 \\
\text { region controls) }\end{array}$ & No & Yes & Yes & Yes & Yes & Yes \\
\hline $\mathrm{R}^{2}$ & 0.107 & 0.108 & 0.109 & 0.122 & 0.140 & 0.125 \\
\hline Observations & 16,031 & 16,031 & 16,031 & 16,031 & 6,540 & 9,491 \\
\hline
\end{tabular}

Notes: This table reports results for the OLS estimation of the relation between patent decentralization and firm sales growth. Share assigned divides a firm's total number of affiliateassigned patents by its total number of patents. Dummy for lab receives the value of one for corporations that have at least one R\&D lab, and zero for corporations that have no recorded R\&D labs. Shares of patents by MSA is a complete set of share variables of the firm patents distribution across 197 geographic regions. In columns 4 and 8 the number of patents are weighed by the number of citations they receive. The weight for patent is the ratio between the number of citations it received and the average number of citations received by all patents that are grated in the same year as the focal patent. Standard errors (in brackets) are robust to arbitrary heteroskedasticity and allow for serial correlation through clustering by firms. **, * denote significance levels of 1 and 5 percent, 
Table 7. Market Value Equation

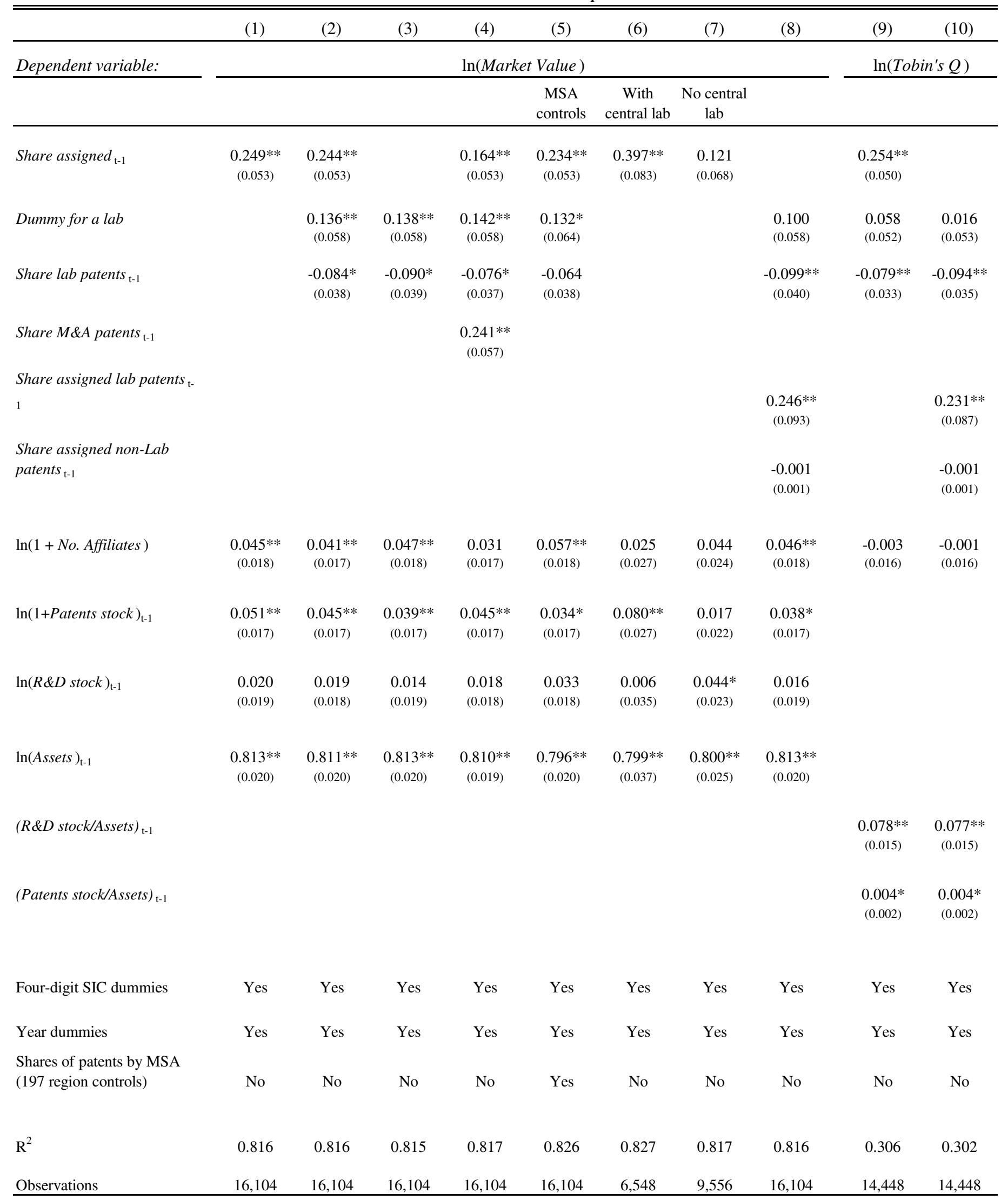

Notes: This table reports OLS estimation results of the effect of patent decentralization on firm market value. The level of analysis is firmyear. Share assigned divides a firm's total number of affiliate-assigned patents by its total number of patents. Standard errors (in brackets) are robust to arbitrary heteroskedasticity and allow for serial correlation through clustering by firms. **, * denote significance levels of 1 and 5 percent, respectively. 